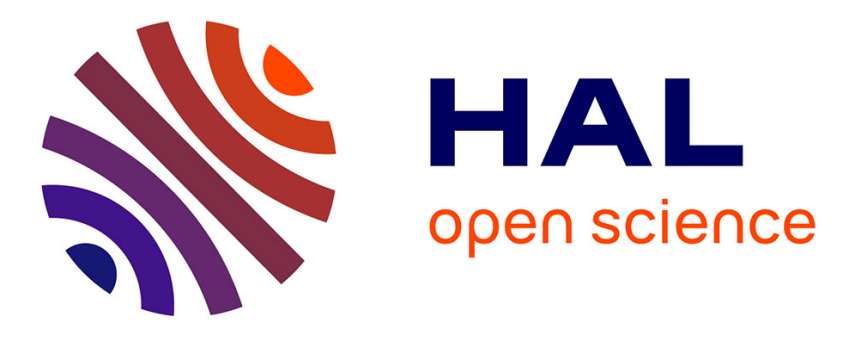

\title{
A review on the coupling of cooling, desalination and solar photovoltaic systems
}

Paul Byrne, Laurence Fournaison, Anthony Delahaye, Yacine Ait Ouméziane, Laurent Serres, Patrick Loulergue, Anthony Szymczyk, Daniel Mugnier, Jean-Luc Malaval, Romain Bourdais, et al.

\section{To cite this version:}

Paul Byrne, Laurence Fournaison, Anthony Delahaye, Yacine Ait Ouméziane, Laurent Serres, et al.. A review on the coupling of cooling, desalination and solar photovoltaic systems. Renewable and Sustainable Energy Reviews, 2015, 47 (juillet), pp.703-717. 10.1016/j.rser.2015.03.083 . hal01145962

\section{HAL Id: hal-01145962 \\ https://hal.science/hal-01145962}

Submitted on 30 Apr 2015

HAL is a multi-disciplinary open access archive for the deposit and dissemination of scientific research documents, whether they are published or not. The documents may come from teaching and research institutions in France or abroad, or from public or private research centers.
L'archive ouverte pluridisciplinaire HAL, est destinée au dépôt et à la diffusion de documents scientifiques de niveau recherche, publiés ou non, émanant des établissements d'enseignement et de recherche français ou étrangers, des laboratoires publics ou privés. 


\section{A review on the coupling of cooling, desalination and solar}

\section{photovoltaic systems}

Paul BYRNE ${ }^{(\mathrm{a}) *}$, Laurence FOURNAISON $^{(\mathrm{b})}$, Anthony DELAHAYE $^{(\mathrm{b})}$, Yacine AIT OUMEZIANE $^{(\mathrm{a})}$,

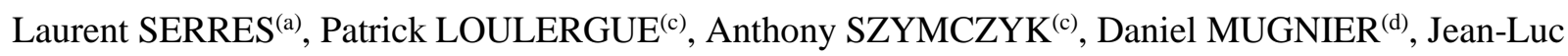
MALAVAL ${ }^{(\mathrm{e})}$, Romain BOURDAIS ${ }^{(\mathrm{f})}$, Hervé GUEGUEN $^{(\mathrm{f})}$, Ousmane SOW $^{(\mathrm{g})}$, Jamel ORFI $^{(\mathrm{h})}$, Thierry $^{\text {. }}$ $\operatorname{MARE}^{(a)}$

(a) Université Européenne de Bretagne

Université de Rennes1, Laboratoire Génie Civil Génie Mécanique, Equipe Matériaux Thermo-Rhéologie IUT Génie Civil, 3 rue du Clos Courtel, BP 90422, 35704 Rennes Cedex 7, France

(b) Institut national de recherche en sciences et technologies pour l'environnement et l'agriculture 1 rue Pierre-Gilles de Gennes, CS 10030, 92761 Antony Cedex, France

(c) Université de Rennes 1, Institut des Sciences Chimiques de Rennes (UMR CNRS 6226)

263 Avenue du Général Leclerc, CS 74205, 35042 Rennes, France

(d) Tecsol

Zone Tecnosud, 105 Av. Alfred Kastler, 66000 PERPIGNAN

(e) NKE SA

Rue Gutenberg, ZI Kerandre, 56700 Hennebont FRANCE

(f) Supelec, Institut d'Electronique et de Télécommunications de Rennes

CS 4760135576 Cesson-Sevigne cedex

(g) Laboratoire d'Energétique Appliquée

Ecole Supérieure Polytechnique de Dakar BP 5085 Dakar Fann

(h) King Saud University

Aldraiyah Area Box 2454 Riyadh, 11451 Saudi Arabia

* corresponding author: paul.byrne@univ-rennes1.fr 


\begin{abstract}
Single cooling and desalination technologies require a high amount of energy to produce cooling and fresh water respectively. Coupling these systems seems to be attractive not only to reduce their energy consumption rates and to gain more flexibility in operation but also for environmental considerations. Besides, using solar energy to drive these coupled systems appears also interesting. The major increases in cooling and desalination demands occur in locations where solar energy is abundant. This article reviews the latest research works on systems able to carry out cooling and/or desalination using solar energy. The ability of coupling desalination technologies to cooling systems is investigated. A heat pump can produce cooling energy at the evaporator and heat at the condenser for a membrane distillation unit. An ice slurry process can operate with sea water. It freezes only pure water that can be separated from the liquid. A comparison of these systems is made. Membrane distillation (MD) and ice slurry systems must improve to be as efficient as standard technologies. An intelligent energy and water production management will have to be developed to control the operation of a system coupling ice slurry, MD and solar photovoltaic energy.
\end{abstract}

Keywords: cooling, desalination, solar energy

\title{
1. INTRODUCTION
}

This article first describes the global context of cooling energy demand and fresh water scarcity and the relationship with the available solar resource. A path for energy savings is the coupling of technologies. The possibility of coupling cooling, water desalination and solar power systems is then discussed by means of a review of systems. Some desalination techniques are identified as adaptable to cooling systems. Finally, a short study is carried out to assess the different chosen coupled solutions.

\subsection{Climate change}

Following the latest report from the International Energy Agency (IEA) [1], the global primary energy supply has increased by approximately 3000 Mtoe (million tons of oil equivalent) since the year 2000 to reach nearly 13000 Mtoe in 2011. The outlook to 2035 shows two trends of total primary energy consumption that constitute 
two boundaries. The trend based on policies under consideration in the concerned countries forecasts a global growth of 4000 Mtoe. The second scenario is based on policies needed to limit global average temperature increase to $2{ }^{\circ} \mathrm{C}$. This scenario would lead to a stabilization of primary energy supply. In both scenarios, energy supply in countries from the Organisation for Economic Co-operation and Development (OECD) will decrease whereas in other countries, it will increase, especially in China and other Asian countries. Global warming is one of the most significant causes of the increase of cooling energy consumption [2-3]. Indeed if the climate is warmer the cooling demand will rise.

\subsection{Population growth}

Beyond the climatic issue, the first reason for the cooling demand increase is the growth of the world population expected to pass from 7 billion in 2011 to 9.3 billion in 2050 [4]. Rural exodus even emphasizes the growth of big cities. Another factor is the urban heat island effect [5]. The proximity of buildings and their cooling equipment creates hot outdoor environment because of the hot air flowing out of the condensers. It provokes higher cooling needs and lower performance of the air-conditioners. The use of condenser heat for desalination would help address this issue. In addition, economic growth of emerging countries where the climate is quite hot in some seasons lead to higher air conditioning consumption. Architectural choices are often not so well adapted to the climate and to the increase of internal gains due to more and more household electrical equipment and ICT (Internet Connected Technologies) devices like computers, smartphones, etc.

\subsection{Buildings}

The building sector accounts for $40 \%$ of the world's energy consumption and one third of total greenhouse gas emissions [6]. Following the Intergovernmental Panel on Climate Change (IPCC) [7], energy saving measures in this sector would be among the most efficient in terms of benefit-cost ratios. Cooling applications already account for an important part of energy consumption. Ren et al. [6] predict that cooling represents $28.3 \%$ of the electricity consumption of a dwelling in Townsville, Australia's largest tropical city. For Sadineni and Boehm [8], the US electricity consumption is devoted at $22 \%$ and $7 \%$ to air-conditioning and refrigeration respectively. In 2011, $23 \%$ of electric energy in French houses is consumed for cooling [9]. The proportion has 
decreased since 1990 but the amount of energy is just stable even when considering the significant effort of manufacturers to produce more efficient cooling systems. The reason is due to the fact that the global sales of air-conditioners have grown from 44 to 94 million units from 2002 to 2012 [10]. There is obviously an important desire of people from developed and developing countries to access higher level of comfort [11]. Cooling demands participate to power outages in regions where the electrical grid shows weaknesses. An IEA document on energy in emerging countries reports the number of power outages per month, their duration and the equivalent lost value estimated as a percentage of sales [12]. In the Middle East and North Africa regions and in the Sub-Saharan Africa, the number of power outages is respectively 10.45 and 14.3 per month. The higher value, 42.18 power outages per month, occurs in South Asia, representing a lost value up to $10.68 \%$ of sales. In these regions, the electricity supply network needs a strong support. The other goal of shifting the peak load is to pay less for energy subscription [13]. According to the IEA, a peak load reduction of $5 \%$ could have reduced the highest wholesale prices by $50 \%$ during California's power crisis in 2000 [14]. Some solutions enable to shift the peak demand using storage systems (ice slurries, cold water, building mass, PCM...) $[13 ; 15$ 21]. Solar energy can also be an interesting way [22]. It can reduce the energy consumption of the cooling technologies as well as the related environmental impacts.

\subsection{Solar energy}

Solar cooling is an interesting way of saving energy. An IEA programme is dedicated to solar heating and cooling systems [23] and until 2013, the main solar cooling approach was developed by coupling solar thermal collectors and sorption solutions (chillers or air handling units). These solutions can provide low-carbon emission energy. As photovoltaic prices strongly decreased, it appeared recently that the simplest way to connect solar energy and cooling systems would now be solar photovoltaic panels providing electricity for a cooling machine compressor. The connection of solar photovoltaic panels to the grid could also be a possible solution to the problem of high electricity demands for cooling [8]. Moreover, the energy consumption of airconditioning systems reaches a maximum when the solar gains are the highest. In the middle of the day, for example, there is a peak demand that has to be supplied by the electric grid [6]. The electricity generation system can be supported by the energy input from solar panels. 
The global installed capacity of PV solar panels is increasing exponentially [24]. It was near to reach the power of $100 \mathrm{GWp}$ at the end of 2012 [25]. This tendency was boosted by the diminution of the cost of solar panels [26] thanks to the price decrease of the main raw material, polysilicon. Ondraczek et al. calculate the Levelized Cost Of Electricity (LCOE) from solar PV systems in 143 countries taking into account the solar resource and the financing cost [27]. The LCOE ranges from $0.30 \mathrm{US} \$ / \mathrm{kWh}$ in Spain up to $7.73 \mathrm{US} \$ / \mathrm{kWh}$ in Zimbabwe with a median value at $0.54 \mathrm{US} \$ \mathrm{kWh}$. In addition, solar panel conversion efficiency (conversion of solar energy into electric energy) is steadily increasing since fifteen years both in R\&D and mass production sectors [24]. Intermittence of solar energy is the most important issue. There are three main solutions: storage of electricity in batteries despite a higher cost or connection to the electrical grid to evacuate the surplus of produced electricity or to supply additional electric energy if the solar PV is not sufficient.

\subsection{Water}

On Earth, $97 \%$ of the water is the saline water of the sea and $2.5 \%$ is frozen fresh water. The last $0.5 \%$, accounting for 10 million $\mathrm{km}^{3}$, corresponds to the available freshwater. However, more than one billion people live without improved drinking water sources [28] and the climate change has also an impact on water scarcity. It changes the proportion of rainfalls in different regions of the Earth [29]. Some zones will have to face serious problems of water supply to populations in the future. Agriculture, industry and energy represent also important consumptions [30]. The freshwater withdrawal is expected to increase by approximately $60 \%$ between 2000 and 2050. One solution to deal with the freshwater resource depletion is to desalinate seawater even if the actual energy requirement per cubic meter of water (safe for human consumption) is still high, between 2.5 and more than $12 \mathrm{kWh}$. The number of desalination systems has increased continuously in the past years totalizing a daily production of 66.4 million cubic metres of desalinated water worldwide in 2010 [31], 71.9 million $\mathrm{m}^{3}$ in 2011 [32] and 81 million $\mathrm{m}^{3}$ in the first quarter of 2014 [33]. A report on the geopolitical issues about water [34] highlights the importance for a country of being independent regarding water supply. A second report for the French government presents the most interesting innovation paths for the industry [35]. Research and development on desalination is one of them. 


\subsection{Cooling demands, solar resource and possible desalination needs}

The correlation between high cooling demands, solar resource and possible desalination needs can be assessed (table 1). The method uses the population of agglomerations and their population growth rate [36]. The data on climate change (temperature increase) and the change in annual precipitation is available in the last IPCC document [29]. The Cooling Degree Days (CDD) and solar resource were calculated using Trnsys software [37]. The cooling degree days are estimated to be the sum (on a yearly basis) of temperature difference between the average outdoor temperature (on a daily basis) and the indoor temperature that a cooling machine should compensate to satisfy the comfort requirements summed over a year. The indoor temperature is estimated at 18 ${ }^{\circ} \mathrm{C}$, a low value to roughly take into account internal gains and solar gains [11]. Table 1 shows that climate change has different impacts on the change in annual precipitations. Fewer precipitations are recorded in Senegal, Saudi Arabia and more are recorded in India and France. The solar resource and the cooling degree days are more or less correlated, except in Mumbai having a hot and humid climate.

Table 1: Comparison of populations [36], growth rate [36], climate change [29], change in annual precipitation [29], cooling degree days [37] and solar resource [37] of five cities

\begin{tabular}{|c|c|c|c|c|c|c|c|}
\hline City & Country & $\begin{array}{l}\text { Population of } \\
\text { agglomeration } \\
\text { (millions of } \\
\text { inhabitants) }\end{array}$ & $\begin{array}{c}\text { Average growth } \\
\text { rate }\end{array}$ & $\begin{array}{c}\text { Climate change } \\
\text { from } 1901 \text { to } 2012 \\
\text { (temperature } \\
\text { variation range } \\
\text { in K) }\end{array}$ & $\begin{array}{l}\text { Change in annual } \\
\text { precipitation } \\
\text { range from } 1951 \\
\text { to } 2010 \text { (mm/year } \\
\text { per decade) }\end{array}$ & $\begin{array}{c}\text { Cooling Degree } \\
\text { Days }\end{array}$ & $\begin{array}{c}\text { Solar resource } \\
\text { (kWh/m² per } \\
\text { year) }\end{array}$ \\
\hline Dakar & Senegal & 2.9 & $4.30 \%$ & $0.8: 1.0$ & $-10:-25$ & 2343 & 2139 \\
\hline Mumbai & India & 21.4 & $2 \%$ & $1.0: 1.25$ & $+10:+25$ & 3435 & 1839 \\
\hline Paris & France & 10.7 & $0.55 \%$ & $1.25: 1.5$ & $+2.5:+5$ & 167 & 1037 \\
\hline Riyadh & Saoudi Arabia & 6.15 & $2.25 \%$ & $0.8: 1.0$ & $-2.5:-5$ & 3061 & 2217 \\
\hline Sydney & Australia & 4.675 & $1.35 \%$ & $1.0: 1.25$ & $-10:-25$ & 646 & 1608 \\
\hline
\end{tabular}

Figure 1 presents the ratio relatively to an average value (superscripts "rel" for relative and "ave" for average) of temperature difference due to climate change (equation 1), Cooling Degree Days (CDD) (equation 2), Solar Resource (SR) (equation 3) and Precipitation Decrease Per Inhabitant (PDPI) (equations 4 and 5).

$$
\begin{aligned}
& \Delta \mathrm{T}_{\text {city }}^{\text {rel }}=\frac{\Delta \mathrm{T}_{\text {city }}}{\Delta \mathrm{T}_{\text {all cities }}^{\text {ave }}} \\
& \mathrm{CDD}_{\text {city }}^{\text {rel }}=\frac{\mathrm{CDD}_{\text {city }}}{\mathrm{CDD}_{\text {all cities }}^{\text {ave }}} \\
& \mathrm{SR}_{\text {city }}^{\text {rel }}=\frac{\mathrm{SR}_{\text {city }}}{\mathrm{SR}_{\text {all cities }}^{\text {ave }}}
\end{aligned}
$$


$P D P I_{\text {city }}^{\text {rel }}=\frac{P D P I_{\text {city }}}{P D P I_{\text {all cities }}^{\text {ave }}}$

$P D P I_{\text {city }}=\frac{\text { precipitation }(\text { year } 2010)}{\text { population }(\text { year } 2010)}-\frac{\text { precipitation }(y e a r 2010)-\text { mean change in annual precipitation per year }}{\text { population }(\text { year } 2010) \times(1-\text { growth rate })}$

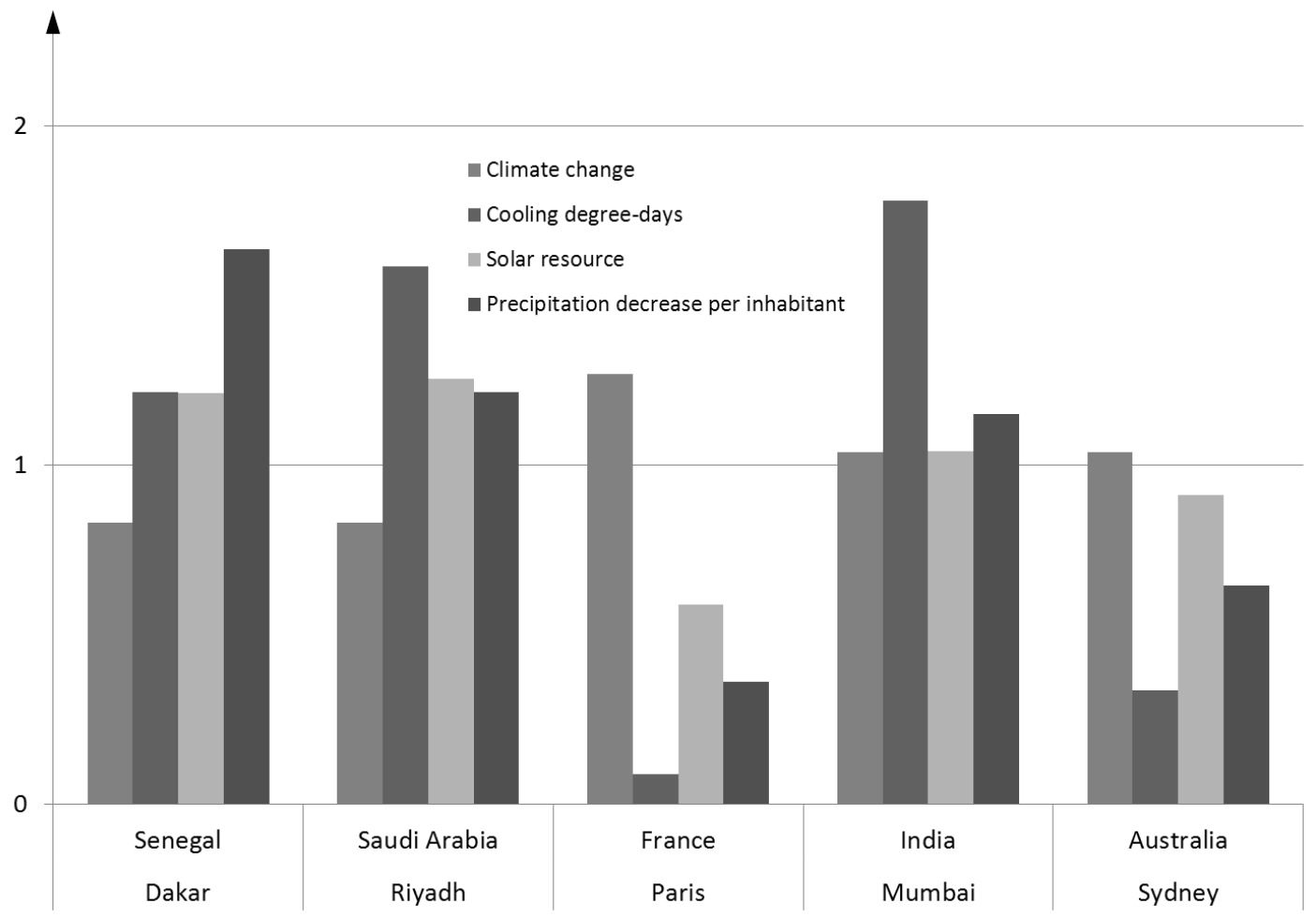

Figure 1: Relationship between relative values of climate change, cooling degree days, solar resource and precipitation decrease per inhabitant of five cities

The last index is calculated as the yearly variation of the ratio of precipitation over population using the present population growth rate and the mean past change in precipitation over 50 years. If this index is positive, the ratio of precipitation per inhabitant is lower than the previous year. For each city, the population growth is such that the water precipitation per inhabitant is lower every year. The water precipitation decrease per inhabitant can be seen as a possible need for desalination. This case is a credible scenario that could be applied by the authorities managing the water supply. However, a lot of further factors can influence the rise of a demand for desalinated water, such as the water consumption evolution due to industry development or the non-use of desalination such as the development of the existing water network if the resource allows it, new technologies for water savings and implementation of good practices. Moreover, the fact that many big cities are near the sea, the recourse to desalination for at least a part of the future water consumption seems unavoidable. In these five cities, figure 1 shows that if the solar resource and the cooling needs are high, the precipitation decrease is 
high as well. To enunciate more general rules about this relationship, the study should be enlarged to other cities having other climates and other population growth rates.

A path for energy savings is to operate a coupling of systems. In this article, the coupling of cooling, desalination and solar photovoltaic systems, two by two, is reviewed to reveal the most beneficial techniques and to investigate their possibility of coupling. The final objective is the determination and assessment of configurations coupling cooling, desalination and photovoltaic systems.

\section{DESALINATION SYSTEMS}

\subsection{Main desalination systems}

Between a pre-treatment (mainly filtration) and a post-treatment (addition of minerals), a desalination plant works following the scheme of figure 2. Saline water enters the system and uses energy to extract a certain amount of freshwater and rejects the rest of the saline water that exits the system more concentrated.

The major desalination processes are presented in figure 3 inspired from a publication of Li et al. [31]. Figure 4 presents the proportions of global freshwater production by the main desalination technologies. The acronyms used in figures 3 and 4 are given in the nomenclature.

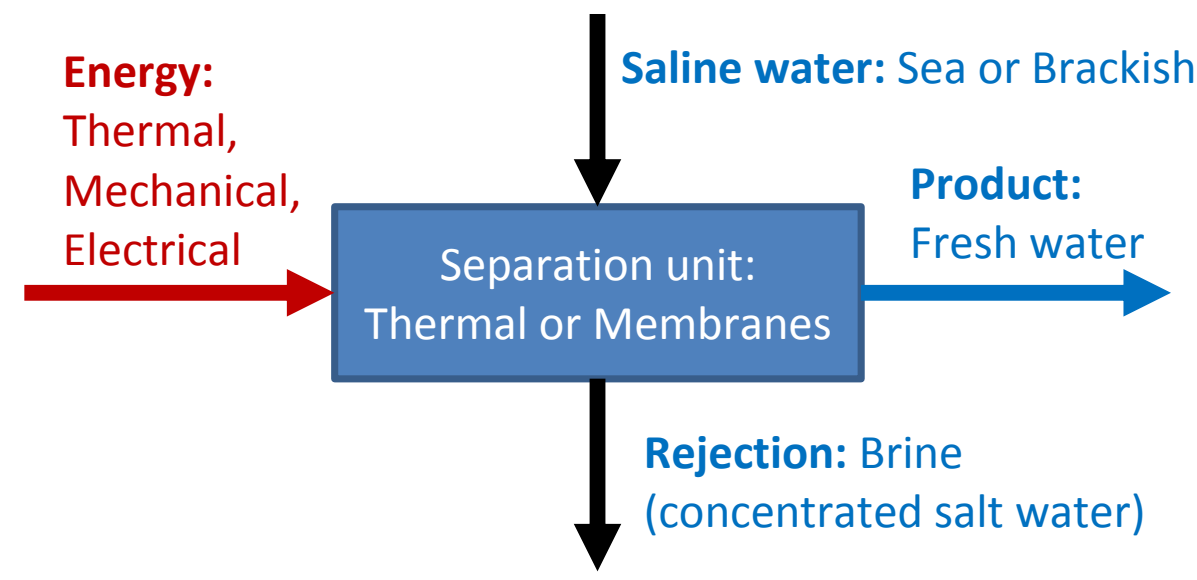

Figure 2: Scheme of a desalination plant 


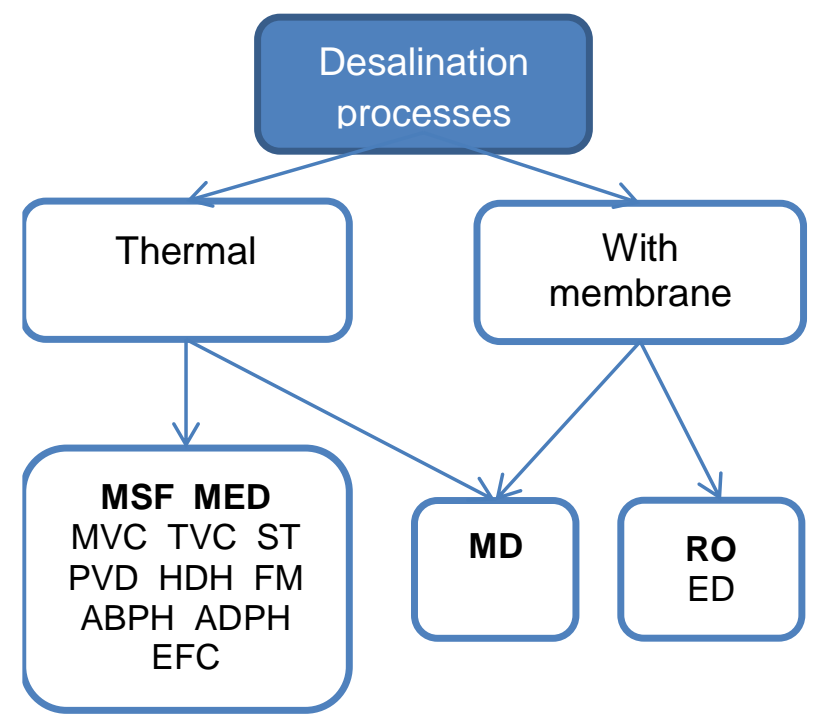

Figure 3: Main desalination processes for freshwater production [31]

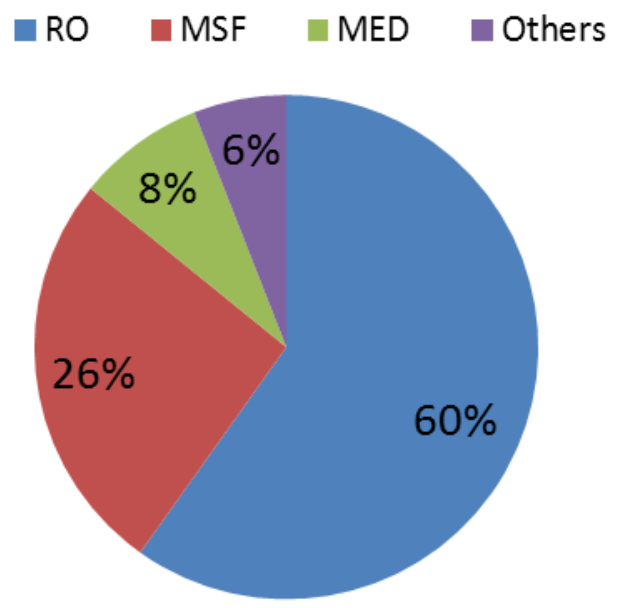

Figure 4: Proportion of installed desalination plants in terms of production capacity in cubic metres per year [31]

Reverse Osmosis (RO), Multi-Stage Flash distillation (MSF) and Multiple-Effect Distillation (MED) are the most common processes. Reverse osmosis is a membrane desalination process in which the feed saline water is compressed to high pressure values. When a concentrated salted solution and pure water are separated by a semipermeable membrane, an osmotic pressure difference exists between the two solutions. The osmotic pressure is dependent on the water salinity. Pure water tends to pass through the membrane from the less concentrated to the most concentrated solution in order to equalize the chemical potential of water in both solutions. If a pressure higher than the osmotic pressure is applied on the concentrated solution, pure water is 
extracted from the salted solution through the membrane. This desalination technique is the most energy efficient. It consumes between 2 to $8 \mathrm{kWh} / \mathrm{m}^{3}$ of electricity (the thermodynamic limit is about $1 \mathrm{kWh} / \mathrm{m}^{3}$ for 35 g/l seawater at 50\% recovery [38] and costs less than $1 \$ / \mathrm{m}^{3}[39]$.

Multi-stage flash distillation produces pure water by boiling then condensing saline water in several vessels (called stages, between 4 and 40) placed in series [39]. The feed water passes through each vessel inside tubes and gets preheated by the condensation energy of the formed water vapour. It is then heated in a brine heater and enters the first vessel in which the pressure is reduced. This lower pressure results in a sudden evaporation of part of the pure water contained in the saline solution (flashing phenomenon). The vapour is condensed on the feed water tubes and then collected. The rest of the solution enters a second stage at an even lower pressure where it flashes again and so on. MSF has proven to be the most reliable desalination technique during the years 1980s and 1990s, before the improvement of RO membranes. The electric energy consumption especially to drive the vacuum pumps is high and is estimated from 3.5 to $5 \mathrm{kWh} / \mathrm{m}^{3}$ but there is also a thermal energy consumption that can be more than $40 \mathrm{kWh} / \mathrm{m}^{3}$. However, the cost of water is still under $1.5 \$ / \mathrm{m}^{3}$.

In order to overcome several disadvantages and limitations including its high specific energy consumption and lack of flexibility, MSF technology operates generally in dual purpose mode where power and fresh water are produced simultaneously. Several alternative and advanced configurations coupling combined power plants and desalination systems have been recently proposed and implemented. These configurations have shown gain in efficiency and in reliability as well as reduction in heat transfer area and cost [40-41]. An example of such projects is the new combined (steam and gas turbine power) and hybrid (MSF and RO desalination) project in Ras Alkhair in Saudi Arabia [42].

Most desalination plants with high water production capacities use heat involved in electricity production of thermal power stations. This kind of process follows the principle of cogeneration. In thermal desalination processes (multi-stage flash, multi-effect distillation...), energy is used to warm up the entering seawater. Only a little part of electric energy is needed for pumping. For example, the plants of Jubail in Saudi Arabia or Jubel Ali in United Arab Emirates, the biggest in the world with a 900,000 $\mathrm{m}^{3} /$ day water production, are supplied by fossil fuels in the evaporation process. More generally, some projects associating a nuclear power station and 
desalination plants are developing. The price competitiveness of the freshwater produced makes this solution interesting [43-44].

Besides, multi-generation concepts have been explored in several recent studies. The work of Jung et al. [45] is an example of such studies. It investigates the feasibility of a tri-hybrid desalination system for the production of electricity, energy for heating and cooling and water. The cooling process in this work consists of an absorption refrigerator.

On the other side, the major desalination techniques are not easily compatible with the operation of a thermodynamic cycle for cooling purpose. RO only needs electricity to run a pump and no thermal energy. MSF requires a too high temperature source for a standard single stage vapour compression cycle. Two innovative desalination technologies are adapted to refrigerating cycles. On the condenser side, the heat can be used in a Membrane Distillation unit (MD). On the evaporator side, Eutectic Freeze Crystallization (EFC) can be operated for cooling and/or desalination. These two techniques are presented in the following sections.

\subsection{Membrane Distillation}

A membrane distillation unit involves the use of a micro-porous and hydrophobic membrane that separates a feed compartment and a permeate compartment. A vapour pressure gradient is created so that part of the pure water contained in the saline water evaporates at the interface and transfers through the membrane. The transferred vapour is then condensed and collected by various ways. One the other hand, due to their low volatility, inorganic ions and macromolecules are concentrated in the feed side and a total rejection can theoretically be obtained [46].

Four basic configurations of membrane distillation process exist [47-50]. Figure 5 describes schematically these configurations. Direct Contact Membrane Distillation (DCMD) and Air Gap Membrane Distillation (AGMD) work with a vapour pressure difference created by a temperature difference. Sweeping Gas Membrane Distillation (SGMD) and Vacuum Membrane Distillation (VMD) work with a lower pressure produced by mechanical means in the right hand channel. 


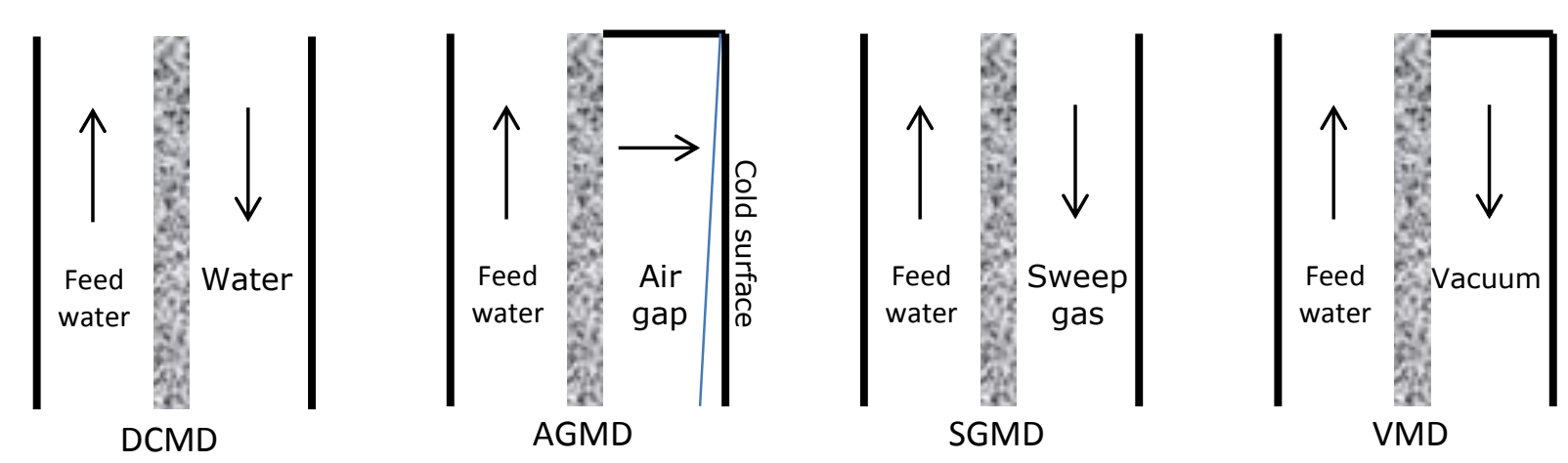

Figure 5: Different types of membrane distillation [47-50]

The air gap membrane distillation is interesting for several reasons [49-51]. The operating temperatures of the feed water are consistent with the condensing temperature of a heat pump. Just like DCMD, AGMD does not require external condenser for water collection. Besides, AGMD is less sensitive to possible membrane wetting than DCMD.

Whatever the configuration, structural, chemical, mechanical and thermal properties of membranes can still be more stable [52] to improve the efficiency of the MD process. First of all, MD membranes must be hydrophobic in order to prevent liquid water entering the membrane. Some of the materials having these typical characteristics are polytetrafluoroethylene (PTFE), polypropylene (PP), polyethylene (PE) or polyvinylidenedifluoride (PVDF) [46-54]. Membranes suitable for MD should also have an average pore diameter in the range $0.1-1 \mu \mathrm{m}$ and a narrow pore size distribution [40;55]. Significant progress has been made in manufacturing membranes suited for MD applications since the 1960's, when membrane distillation was first proposed. Thus, membranes with satisfying features are now affordable, which has allowed the construction of the first seawater desalination plant based on MD technology in 2014 [54].

Membrane distillation seems economically interesting if coupled to a renewable energy source [50]. Why then did it not emerge? Several limitations are still under investigation. MD membrane technology still has to develop to provide higher flux and lower wettability. Some problems are related to temperature and concentration polarization as well as the high required energy consumption compared to RO process. The MD processes experience difficulties to scale up to commercial units [33]. The multistage concept has been implemented recently. Other thermal desalination systems operate with higher temperatures that can come from solar collectors or wastes of processes [56]. Membrane distillation operating in a range of lower temperatures might 
have found an interesting coupling with the condenser of a chiller. This coupling is new to the authors' knowledge.

\subsection{Eutectic Freeze Crystallisation (EFC)}

Fujioka [57] reports that freeze desalination has some advantages when compared with other methods. One of the main advantages of freeze desalination systems is its energy consumption. It requires only $420 \mathrm{~kJ}$ to remove salt and produce $1 \mathrm{~kg}$ of fresh water, which is six times lower than what MSF requires [58]. In addition to that, freeze desalination system is insensitive to corrosion problems because of the low operating temperature and can operate for a long time with little maintenance [58]. However, there are some problems in operating this kind of plant; one of the most troublesome is ice handling after the desalination process [59].

A continuous EFC system based on direct cooling in a mixed crystallizer followed by salt-ice separation has been developed at the bench scale [60]. Crystallization was achieved by indirect cooling with wiped disks and separation by means of gravity. In this system, the liquid feed stream enters the column at the centre, while ice leaves the column at the top and salt is discharged from the bottom. When compared to conventional evaporative crystallization, the energy required for EFC can be reduced by up to $70 \%$ and the $100 \%$ conversion into water and salt is an advantage [64]. EFC system analysis and modelling have been conducted to simulate its transient behaviour [61-63].

Fernandez Torres et al. [65] consider that Eutectic Freeze Crystallisation (EFC) is a new promising technology that has the potential to compete with evaporation crystallisation but so far has not been built at industrial scale utilization. This technology is thought to be able to reclaim good quality water [66]. Its energy consumption has been claimed to be significantly lower than that of alternative technology [67]. When deployed for the beneficiation of waste material, the process might thus be thought to be environmentally friendly or even "sustainable". Nonetheless, such claims of superior environmental performance should not be made without a rigorous environmental assessment. 


\section{COUPLING OF SYSTEMS}

In this section, previous works on the coupling of solar photovoltaic, cooling and desalination systems are presented. In general, the conclusion is a better performance despite a more complex operation.

\subsection{Solar desalination}

Because desalinated water demands involve countries with solar resource, solar energy seems suitable for use in desalination processes. However, the solar system representing a very large part of the overall system cost, it needs to be carefully selected [31]. In thermal desalination processes, solar energy can be used as a heat source with solar thermal collectors. During the last decades, many solar driven systems have been developed and improved [30]. The majority of these solar thermal desalination systems based on solar still configuration, humidification-dehumidification and membrane distillation processes have a major limitation related to their small capacity of water production rates. They can be used in remote rural areas. Mittelman et al. [68] presented a review study on large scale solar thermal desalination plants. The study focussed on the development of solar collection systems coupled with multiple effect distillation process. The technical and economic issues of some experiences on MED integrated with evacuated tube collectors, with parabolic trough collectors as well as with compound parabolic concentrator collectors have been presented and discussed [68]. For membrane processes, solar energy is used to produce electricity. Two systems were recently mostly studied: Concentrated Solar Power (CSP) and photovoltaic (PV). As presented by Li et al. [31], with the exception of solar pond driven desalination systems which do not need solar collectors, all other configurations have more than $25 \%$ additional cost for solar collectors. Membrane systems powered by CSP or PV are compared by Colombo et al. [69]. The most studied membrane process studied is RO, appearing as one of the most efficient system. In CSP, steam is produced by the collector and driven to a turbine connected to an electrical power generator. Combined with a reverse osmosis system, the CSP system is regarded as one of the best choices for solar desalination [70]. This use of solar energy presents the advantage of using a thermal storage system for longer hours of operation after sunset and the ability to use a backup fuel for unexpected conditions. This system is particularly interesting for large-scale installation. Nevertheless, CSP presents some disadvantages compared to PV. Indeed, because of its 
principle, only direct solar irradiance takes part in the electricity production. In cloudy conditions, the latter is significantly reduced. Besides, the implantation of such a structure in coastal areas is disturbed by oceanic climates with high relative humidity which affect the direct solar irradiance. PV systems convert sunlight directly into electrical energy and can be used at different scales.

\subsection{Focus on solar PV desalination with reverse osmosis}

If initially the most common desalination technique was thermal distillation, reverse osmosis has become at the end of the twentieth century the most popular technique [71]. The progress in membrane design and materials and the use of energy recovery systems supported the development of this technique. This success is probably due to a very good efficiency [71] and to low ratio of energy consumption per $\mathrm{m}^{3}$ of fresh water (as low as 2 $\mathrm{kWh} / \mathrm{m}^{3}$ for research prototypes and $4 \mathrm{kWh} / \mathrm{m}^{3}$ for plants in production [72] when desalinating seawaters). Paradoxically, it seems that this low need of energy is one of the reasons of the weakness of the development of the coupling of renewable energies and reverse osmosis. The other obstacle is that the price of renewable energy is higher than conventional energies [73], particularly in the oil-rich and very sunny regions. Indeed the most interesting renewable energy for coupling with reverse osmosis seems to be a photovoltaic system [73]. Then two solutions seem to be interesting for future development. Firstly, small plants for isolated users, in regions where there is no electrical network and where density of population is low. The principle is then to produce electricity with PV panels to feed pumps of the reverse osmosis system. Secondly some highly populated areas (like Thailand, India, and Bangladesh) do not have easy access to oil but are well placed to use solar energy for desalination [74]. The process could consist in hybriding large solar plants which will produce power and fresh water [71] by solving in this way the problem of electricity storage. The PV plant would produce power if there is a need of electricity, and fresh water otherwise.

\subsection{Solar cooling}

Solar cooling is an important subject of research. Ferreira and Kim [75] present a review article on technoeconomic assessment of solar cooling systems. The correlation of solar resource and cooling demand over a day is presented for Spain and the Netherlands. A variety of solar cooling possibilities is offered with thermal 
energy. Photovoltaic panels or solar parabolic panels supplying heat to Stirling engines, coupled to a vapour compression refrigerating machine is seen as a serious option for solar electric energy. With their hypotheses, investment and running costs are lower than with thermal systems. Other studies also concluded to favourable results for solar PV cooling [76-77] anticipating the lowering of the cost of PV and the improvement of modules. Aguilar et al. [78] studied the operation of an air conditioner directly connected to PV panels and to the grid. This commercial coupled system has shown interesting performance during a long term monitoring. The main issue on this project was the electricity and thermal energy management.

Herrera et al. [79] worked on predictive and interactive controllers for solar absorption cooling systems in buildings. They highlight the complexity of controlling a system powered by a variable energy source. The predictive characteristic associated with the interactions among controllers improves the performance and the safety of the system, whereas the complexity of the control and the communication requirements remain low.

The advantages of solar cooling are to propose stand-alone plants or to participate in managing the peak load on the electric grid of a location. One real problem relies in the use of batteries lowering the global system performance due to conversion factors and having high installation and maintenance cost. Photovoltaic panels can be connected to a DC/AC converter providing AC current for a standard compressor or directly connected to a compressor having a DC current brushless motor. Today both solutions can be envisaged thanks to the improvement of commutation components brought by the car industry and the household electrical industry; the characteristics of the components in terms of tension, power and efficiency have improved while prices have decreased. The compressor, named "inverter" compressor, can be equipped with a variable speed motor. This technology is usually used to adapt the thermal production of a heat pump or a refrigerating machine to a thermal load. However, this technology can be used on the other way: the production of freshwater and thermal energy can be a function of the available power provided by solar PV. One of the main issues to overcome regarding the coupling of solar PV energy and a refrigerating machine is the control of the whole system. In the application for buildings, the possibility of a connection to the electric grid has also to be taken into account. Moreover, other electric devices could be powered by the electric PV production. 


\subsection{Cooling and desalination}

Slesarenko presents a heat pump integrated with a desalination process and working with steam [80]. However the heat pump does not carry out cooling. A simulation study was carried out by Byrne et al. [81]. It evaluates the performance of the coupling of a heat pump and an air gap membrane distillation unit. A comparison with the association of a chiller and a reverse osmosis desalination plant is proposed in the following studies [8283]. Other techniques using for example adsorption chillers can be employed to carry out simultaneous cooling and desalination [84]. However the cooling effect is more or less a by-product of the desalination process.

\subsection{Solar cooling and desalination}

Some examples of coupling of solar PV, cooling and desalination can be found. IBM develops concentration solar panels named "sunflowers" to supply off-grid energy, water and cooling [85]. The desalination system is a vacuum membrane distillation system. The cooling energy is produced by an adsorption chiller. Fraunhofer ISE presented a simpler cooling and RO desalination system powered by a PV array [86]. A smart mini-grid is integrated for electricity supply. Two other propositions of systems are presented in this article.

\subsubsection{Heat pump + membrane distillation unit + solar photovoltaic energy}

Byrne et al. work on heat pumps for simultaneous heating and cooling (Figure 6) [81]. Innovative architectures have been designed with the objective to be energy efficient and well suited for low-GWP refrigerants such as hydrocarbons [87] or carbon dioxide [88]. The heat produced was thought of being suited to desalination by a membrane distillation unit (Figure 7) [81-83]. The heat pump compressor is connected to a solar photovoltaic energy system.

The principle of the system is the following. A heat pump is used for cooling spaces or refrigerating cabinets and heating saline water. The hot saline water is then provided to a membrane distillation unit. The compressor is connected to solar photovoltaic panels and batteries to be possibly used in isolated locations or the electric grid. 


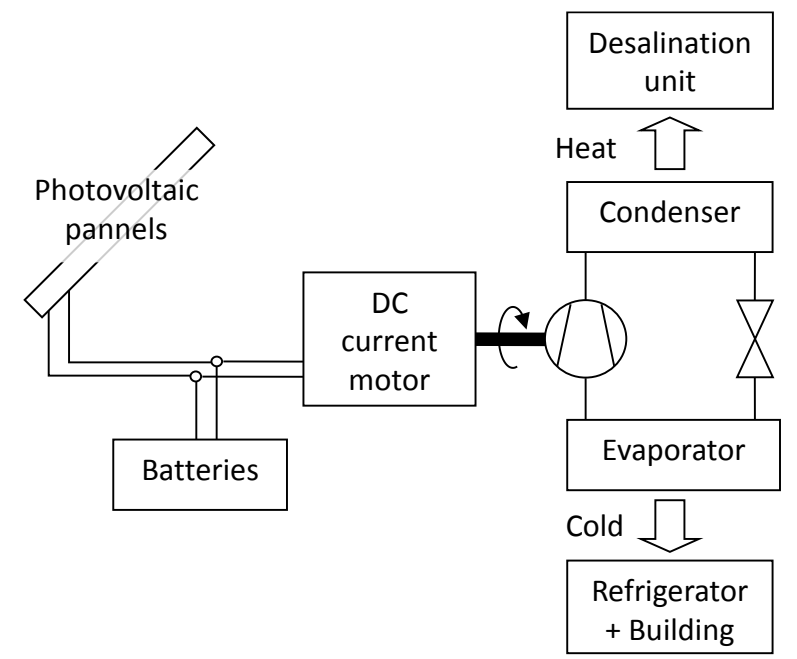

Figure 6: Heat pump for simultaneous cooling and desalination powered by solar PV [81]

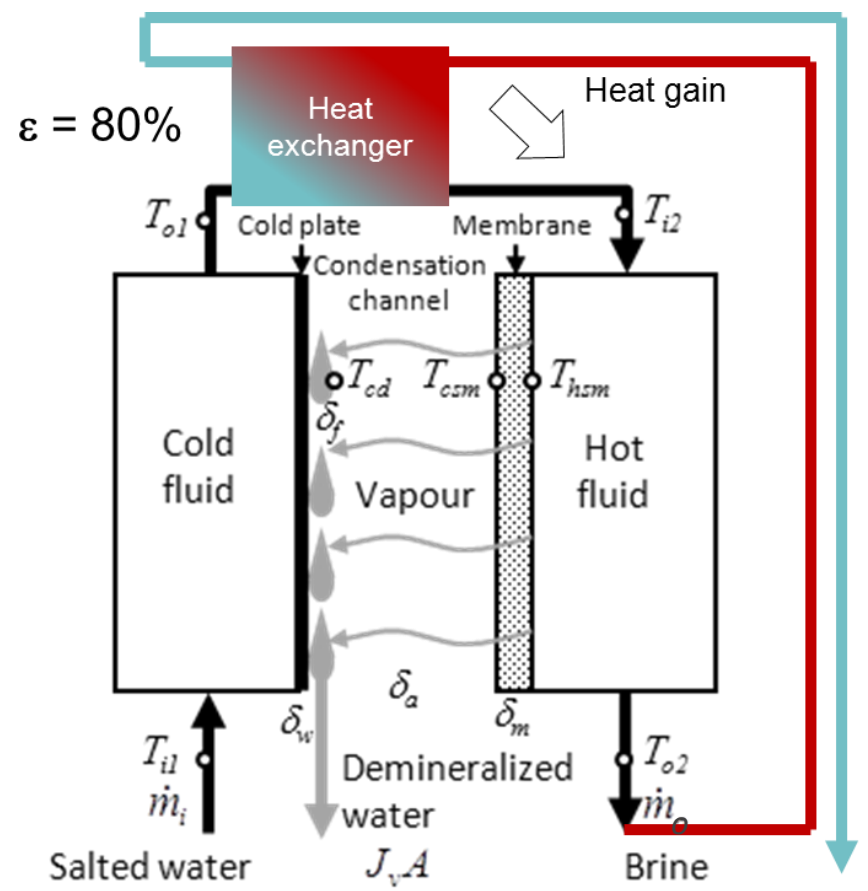

Figure 7: Membrane distillation unit principle [81-83]

The distillation unit is constituted of two water channels between which a heat transfer is established. Seawater flows inside the cold channel is heated by the condensation energy of the heat pump then circulates in the hot channel. The channels are separated by a micro-porous and hydrophobic membrane, an air gap and a metallic plate on the cold channel side. Due to its hydrophobic characteristic, the membrane allows only a water vapour flow, linked to the temperature gradient, to enter the air gap and condense on the cold plate. Desalinated water is thus obtained. 
Simulation studies were already published on the efficiency of this process [81-83]. The model was built in accordance with experimental results from a previous thesis [89]. The temperature gradient was found to be interesting over a value of $20 \mathrm{~K}$. The simulation results obtained with the weather data file of Ouagadougou gave values of $1687 \mathrm{kWh}$ of thermal energy per $\mathrm{m}^{3}$ of desalinated water produced, which is to be compared to the ratio of $665 \mathrm{kWh} / \mathrm{m}^{3}$ to evaporate water at a temperature of $50^{\circ} \mathrm{C}$. The implementation of a heat exchanger to preheat the sea water before entering the hot channel by the energy of the brine and the system optimization decreases the energy requirement to a value of $358 \mathrm{kWh} / \mathrm{m}^{3}$.

\subsubsection{Ice slurry process for cooling and desalination + solar photovoltaic energy}

Ice slurry is a widespread technology for secondary refrigeration or storage [90]. They are many plants in Asia, especially in Japan, where the energy cost is high. Ice slurries are aqueous solutions containing fine ice crystals. They are generated by special heat exchangers, which bring the aqueous solution below their freezing temperature. The aqueous solution can be for example, ethanol, ammonia or sodium chloride. These ice slurries are used for secondary refrigeration and become very efficient when connected to a storage tank. For this purpose, ice slurry is generated in the heat exchanger, and then pumped towards the places of use. When heat is delivered to the ice slurry, the ice crystals melt. This allows maintaining the fluid temperature stable. Therefore, the evaporating temperature can be higher than when using a single phase fluid where sensible heat is exchanged. In order to minimize the energy losses generated by the use of a pump, the ice fraction is limited to $30 \%$.

The efficiency of the ice slurry is increased when connected to a storage tank. Indeed, due to different external conditions, the efficiency of the refrigerating unit is enhanced during the night, and the stored capacity can be used when the cold demand is high.

This technology is also well adapted to desalination, as the crystals contained in the slurry are made of pure water [91-92]. The real issue here is to have an efficient way of separating the ice from the slurry. This combined system will then be able to produce at the same time "clean" water and cold. Optimization is then requested in order to determine the best strategies to operate depending on the needs. 
Ice slurry technology has never been connected to solar cooling at the industrial level. The feasibility of this technology must be evaluated as well as the best strategy to use depending on the needs.

Generally the ice slurry generators are scrapped or brushed heat exchanger type. Indeed, the water contained in an aqueous solution freezes on a cold surface, and scrappers are used to remove the crystals from the surface.

In agro food industry, scrapped surface heat exchangers are commonly used, for example ice cream formation. They are composed of 2 coaxial tubes, between which a refrigerant evaporates to produce the cold. In the middle, scrapers rotate in the same axes as the tubes to remove the ice, and also to act as a mixing device.

Desalination by freezing is based on the liquid-solid phase change of the water contained in the sea water. According to thermodynamics, the ice formed from the sea water is pure. It can be separated from the concentrated solution and then melted to obtain fresh water. Crystallization has the advantage of having low energy consumption. The freezing processes can be divided into three categories: primary vacuum freezing, freezing secondary and indirect freezing [93].

a) Primary freezing (vacuum)

This type of processes is all continuous processes. They directly use the water contained in the sea water as a coolant. At reduced pressure, the water evaporates and extracts the heat from the brine, which leads to a partial freezing of the solution. The crystals formed are washed in a column and melted. All these methods require a special pretreatment of sea water which has to be degassed to remove dissolved air. This type of freezing encounters mechanical issues connected to the compressor type, but the flow rate can reach up to $1000 \mathrm{~m}^{3} / \mathrm{h}$.

\section{b) Secondary freezing}

The technique works in continuous mode and uses an inert cold refrigerant immiscible with the seawater. The cold refrigerant, under pressure and in liquid state is injected directly into the seawater. This causes vaporization which cools the solution and provides the ice crystals formation [94]. Ice crystals are then separated from the brine, passed into the wash column and sent to the melting device. The refrigerant vapour is compressed and 
then condensed by heat exchange with the ice crystals in the melting device. The chosen refrigerant is n-butane which is cheap, plentiful and relatively environmentally friendly.

This type of freezing encounters contamination of refrigerant by brine which affects the performance of the compressor.

c) Indirect freezing

The enthalpy needed for partial freezing of the sea water is removed by indirect heat transfer through a wall. The indirect freezing methods can be operated in continuous mode or batchwise. Continuous processes lead to the formation of ice crystals in suspension. These suspensions are obtained by seeding avoiding deposition on the cold surface [95] or by scraping the ice layer formed on the cold surface. In both cases, the ice crystals suspended in the brine, are then washed and melted respectively in wash columns and melting. In the indirect batch process, a layer of ice is formed on the cold solid surface. Stages of freezing, drainage or bleeding, and melting are performed in the same device. Ice formed undergoes partial melting drainage until the residual ice is potable [96]. The indirect freezing method by batch has the advantage of being less complex than the other methods of freezing. This process can deliver around $200 \mathrm{~m}^{3} / \mathrm{day}$.

This type of freezing presents the highest energy consumption compared with direct process as the temperature difference is higher due to the additional heat exchanger [95].

There is now however a positive attitude toward freezing because of the benefits it presents, and thanks to technological development that solves most problems. Freezing on a cold wall by indirect contact is a simple process, which seems to be promising. There is great potential for freezing with the combination of other desalination techniques, especially with reverse osmosis. One study showed that the hybrid method is more economical than separate units [96]. Besides, small desalination units by freezing can be powered by solar energy [95] (photovoltaic system or the Rankine cycle) or with wind energy. One could also imagine a heat pump absorption using solar energy as a heat source to produce the required cold by freezing. Finally, the desalination plant could be coupled to an air conditioning system (a hotel, for example). 
The production of pure water by freezing is a possibility studied by many authors. Initial investigations have been conducted on the formation of large volumes of ice that have major drawbacks such as trapping impurities in the block of ice, and the slow kinetics of ice formation. So many ice formation techniques have been studied such as the formation of ice on evaporator (falling film) with alternating freezing on two exchangers.

A new development lead seems promising: the use of ice slurry. This technology is based on the formation of ice crystals having an average size of 100 micrometres suspended in an aqueous solution. Sea water is a solution containing about $5 \%$ salt; its freezing is initiated at $-3.1{ }^{\circ} \mathrm{C}$. If the temperature is lowered, the solution is enriched in pure water ice. The evolution of the ice mass concentration as a function of temperature is illustrated in the following figure for a concentrated salt solution of 5\%.

Ice slurries are composed of water with ice crystals mixed with another fluid such as alcohol, $\mathrm{NaCl}$ or ammonia. They are formed by means of generators which can lower the temperature of the aqueous mixture below the temperature of phase change of the aqueous mixture. For secondary (or indirect) cooling the slurry formed is pumped towards each place of use. The cooling is provided by melting the ice crystals. In this context, in order to limit pressure drop, the ice concentration should not exceed $30 \%$. This system becomes more effective if connected to a storage system. Indeed, nocturnal climatic conditions can increase the efficiency of the refrigerating machine, and the stored heat can be used for peak shaving during daytime use.

This technology is also suitable for desalination, since it allows meanwhile the production of pure water ice. The production of cold water can be performed simultaneously or separately. Optimization strategies should be studied according to the local needs.

The principle of ice slurry generation is shown in figure 8. Frequently used in the food industry, these exchangers are composed of two coaxial tubes between which a refrigerant evaporates. Inside, a cylindrical rotor equipped with blades rotates in the same axis of the tubes. A secondary refrigerant mixture (sea water) flows through the inner tube; the crystallization occurs on the inner wall of the tube and forms an ice layer and the wall scraping with the blades delivers the dispersed phase. Rotation of the shaft allows a further improvement of a heat exchange and renewal of the brine in contact with the exchange surface. 


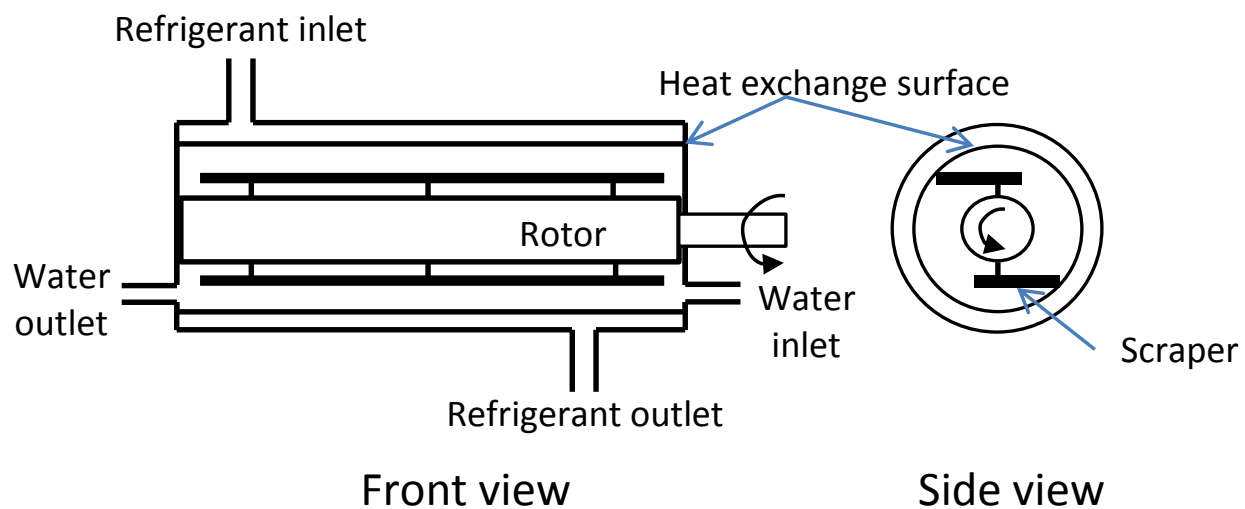

Figure 8: Scraped surface heat exchange. The brine crystalize on the inside wall; the ice is scraped and forms the dispersed phase of the diphasic secondary refrigerant.

In this case, the exchange surface between the liquid crystals and the liquid solution is much higher than the wall on which the ice grows during crystallization. The growth rate can be moderated in the slurry processes. This slow growth achieves ice crystals of high purity. In the desalting methods, ice is contaminated with salts during freezing for kinetic reasons, and by the brine itself during the ice separation;

The method should minimize the contamination. The unit operations of freezing desalination are:

1. The formation of ice crystals from the salt solution (for slurry processes, large crystals are desired to facilitate washing),

2. Washing and / or "drying" of crystals

3. The melting of the ice crystals.

Solar photovoltaic panels can be the power source of the compressor of the ice slurry refrigeration machine. The solar energy available can be entirely transformed into thermal energy for seawater cooling and ice formation. Indeed, the storage brought by the latent heat of water solidification enables to use directly the solar radiation without any electricity storage. On the one hand, the liquid and ice separation will define how much fresh water will be produced. On the other hand, the amount of cooling energy in the ice and in the liquid can be recovered for air-conditioning or food preservation.

\section{ASSESSMENT OF COUPLED SYSTEMS}


This section presents a quick performance evaluation of simultaneous cooling and desalination systems without taking into account the power source. The objective is to identify the most interesting system; in other words, the one having the lower amount of electricity consumption per cubic meter of desalinated water for the same cooling energy production. The systems are (1) a HPS coupled to MD, (2) an ice slurry system, (3) ice slurry and MD coupled systems and (4) a vapour compression chiller associated to a RO unit. System (4) is considered as the reference system. A review summary first concludes on the possible technologies used for simultaneous cooling and desalination and their key factors for implementation. Then the methodology for performance calculation is given and finally the results for varying operating conditions are presented and discussed.

\subsection{Review summary and key factors for development}

The path of coupling technologies for energy savings seems interesting. Numerous research works confirm this statement. Table 2 summarizes the main technologies involved, the state-of-the-art, the technical barriers of each coupled system reviewed in this article. The research trends explored by the scientific community will have to overcome these technical barriers. The main conclusions are the following:

- desalination powered with PV is dominated by RO technology,

- the equipment at a commercial state is the most common,

- thermal desalination has to be coupled to become economically interesting,

- the common key factor of coupled systems is the control management of resource and productions.

A roadmap for the development of desalination powered by renewable energy [97] highlights the numerous technological, economical, institutional and social barriers that have to be overcome to envisage a wider implementation of coupled solar energy desalination systems, especially small scale ones. This report proposes paths to facilitate market entry, especially the promotion of the cooperation on R\&D between academics and manufacturers of complementary components and control devices through joint research projects.

Table 3 summarizes the technical, socio-economic, environmental, policy and legislative key factors that have to be taken into account for implementation of a cooling and desalination project powered by PV on a coastal area or in a remote inland region. Some big cities like Riyadh in Saudi Arabia necessitate and already use 
desalinated water form brackish water sources. In this case data from both columns could apply. The cooling applications for coupled systems would be in majority air-conditioning for collective residential buildings or hotels in cities because in office buildings fresh water demands are too low. In remote villages, the cooling application is expected to regard more food conservation.

The extraction of feed water, the manufacture and operation of the cooling and desalination unit, the rejection of brines will have an environmental impact that has to be carefully studied. The study of the environmental impact is also part of the socio-cultural issue. If favourable, it will participate in the acceptance of such systems. Indeed, desalination being perceived negatively by a part of the populations, communication, education and training should be promoted. A report on the best desalination technologies in rural and local zones [98] was asked by the SWIM (Sustainable Water Integrated Management) support mechanism financed by the European Union. The Global Water Partnership (GWP) is presented as an international network of institutional agencies, associations and private actors to promote the use of an Integrated Water Resource Management (IWRM). IWRM is based on social equity, economic efficiency and ecological sustainability. This water management policy may conclude in favour of desalination in some cases. On the economical point of view, the answer would be first to establish detailed market analyses, then to organize trade missions with the help of specialized agencies such as SWIM and finally to support financing programs for acquisition of systems. Lobbying should be carried out in institutions to facilitate administrative formalities and cooperation between water and energy sectors for simpler implementation. 
Table 2: Summary of the review on coupled systems

\begin{tabular}{|c|c|c|c|}
\hline Coupling & Main technologies & State of the art & Main technical barriers \\
\hline $\begin{array}{l}\text { Solar PV + } \\
\text { Desalination }\end{array}$ & PV + RO [30;68;70-73] & Commercial & $\begin{array}{l}\text { Electricity management for } \\
\text { desalination and power supply }\end{array}$ \\
\hline $\begin{array}{l}\text { Solar PV + } \\
\text { Cooling }\end{array}$ & PV + Air conditioners [75-78] & Commercial & $\begin{array}{l}\text { Solar resource, thermal energy } \\
\text { and electricity management }\end{array}$ \\
\hline \multirow{2}{*}{$\begin{array}{l}\text { Cooling }+ \\
\text { Desalination }\end{array}$} & EFC [91-95] & Research & $\begin{array}{l}\text { Use of thermal energy for cooling } \\
\text { Solid liquid separation }\end{array}$ \\
\hline & HPS + MD [81-83] & Simulation & $\begin{array}{l}\text { Membrane material improvement } \\
\text { System management }\end{array}$ \\
\hline \multirow{5}{*}{$\begin{array}{l}\text { Solar PV + } \\
\text { Cooling + } \\
\text { Desalination }\end{array}$} & PV + adsorption + VMD [85] & \multirow{2}{*}{$\begin{array}{l}\text { Industry } \\
\text { projects }\end{array}$} & \multirow{5}{*}{$\begin{array}{l}\text { Component development } \\
\text { System management }\end{array}$} \\
\hline & $\begin{array}{l}\mathrm{PV}+\text { vapour compression + RO } \\
{[86]}\end{array}$ & & \\
\hline & $\mathrm{PV}+\mathrm{HPS}+\mathrm{MD}[81]$ & \multirow{3}{*}{$\begin{array}{l}\text { Beginning } \\
\text { research }\end{array}$} & \\
\hline & PV + EFC (present article) & & \\
\hline & $\mathrm{PV}+\mathrm{EFC}+\mathrm{MD}$ (present article) & & \\
\hline
\end{tabular}

Table 3: key factors for development of coupled cooling, desalination and PV systems

\begin{tabular}{|c|c|c|}
\hline Site & $\begin{array}{l}\text { Coastal areas } \\
\text { (in cities) }\end{array}$ & $\begin{array}{l}\text { Inland regions } \\
\text { (in villages) }\end{array}$ \\
\hline Interest for PV & Peak load management & Power source \\
\hline $\begin{array}{l}\text { Main cooling } \\
\text { application }\end{array}$ & $\begin{array}{l}\text { Air-conditioning for collective } \\
\text { residential buildings }\end{array}$ & Food conservation \\
\hline Water source & Sea water & Brackish water \\
\hline $\begin{array}{l}\text { Main technical } \\
\text { requirements }\end{array}$ & High performance & $\begin{array}{l}\text { Simple and reliable system with easy } \\
\text { maintenance }\end{array}$ \\
\hline $\begin{array}{l}\text { Environmental impact } \\
\qquad[98]\end{array}$ & \multicolumn{2}{|c|}{ 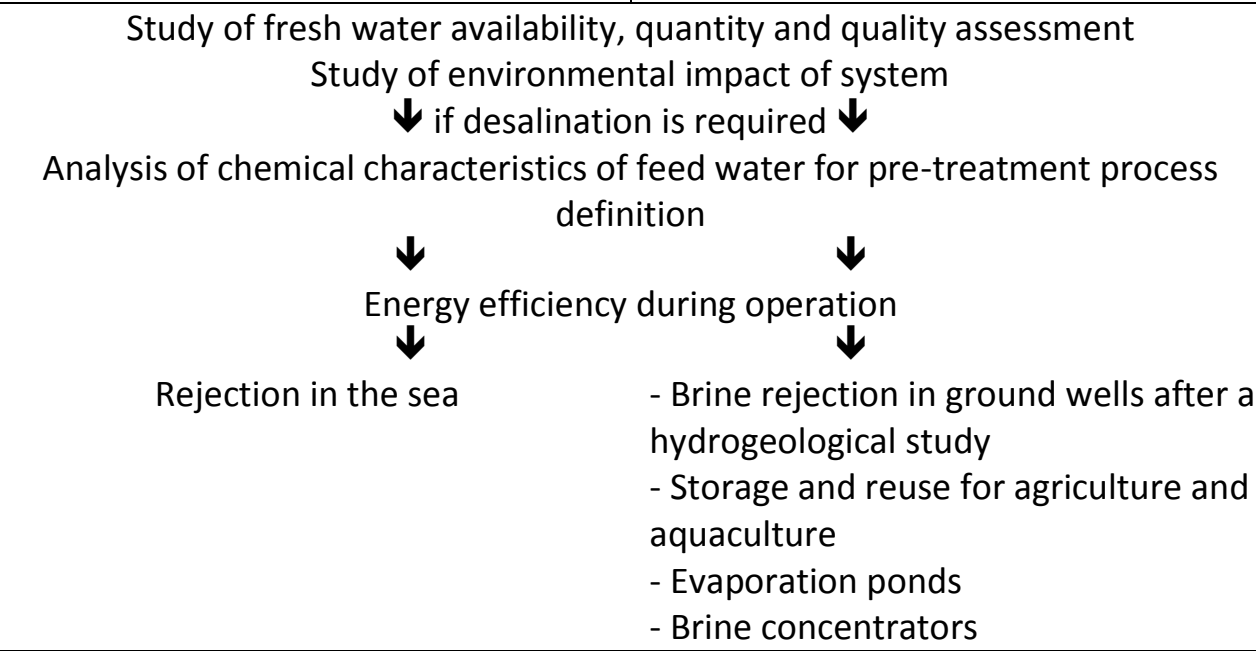 } \\
\hline Socio-cultural issue & Necessary information to consumers & $\begin{array}{c}\text { Necessary implication of populations } \\
\text { for system acceptance }\end{array}$ \\
\hline \multirow{2}{*}{ Policy and legislation } & \multicolumn{2}{|c|}{ Integrated Water Resource Management (IWRM) in favour of desalination } \\
\hline & $\begin{array}{l}\text { Facilitation from national authorities } \\
\text { or city councils }\end{array}$ & Local incentives and/or subsidies \\
\hline
\end{tabular}




\subsection{Methodology for performance assessment}

The methodology is based on the first simulation results obtained in a previous publication [82] with a HPS coupled to a MD unit. The refrigerating machine characteristics simulated in that article are the same for all systems in the present study. The cooling energy production is set equal for all systems. The water production depends on the desalination system. They are set equal for systems (3) and (4), assuming that the RO unit produces the same volume of desalinated water as the coupled ice slurry + MD process. The system EER (energy efficiency ratio) depends on the source temperatures that change from one system to another. Electric energy consumptions for cooling are calculated using the EERs. The EERs of thermodynamic cycles are calculated using Coolpack application [99] developed with EES software [100]. Propane is chosen as a refrigerant. Default values of Coolpack were taken for the superheat degree $(5 \mathrm{~K})$, the subcooling degree $(2 \mathrm{~K})$, the pressure losses in the suction and discharge lines converted into temperature discrepancy $(0.5 \mathrm{~K})$, the compressor heat loss factor (10\% of compression work) and the unuseful superheat degree $(1 \mathrm{~K})$. The compressor isentropic efficiency (0.668) was adapted to obtain the same EER as in a previous study that resulted in a ratio of 358.2 $\mathrm{kWh}$ of electric energy consumption per cubic metre of desalinated water using an AGMD unit [82]. The EER is defined by the ratio of the cooling energy produced by the refrigerating machine $Q_{c}$ over the electric energy absorbed by the compressor $W$ (equation 6).

$\mathrm{EER}=\frac{\mathrm{Q}_{\mathrm{c}}}{W}$

All heat exchangers losses are neglected. The internal heat exchanger for energy recovery from the brine before the heat pump condenser that heats the sea water (in figure 7) has an efficiency of $80 \%$. The temperature pinches are $7 \mathrm{~K}$ between air and refrigerant temperatures and $5 \mathrm{~K}$ between water and refrigerant temperatures. The sea water inlet temperature is $20^{\circ} \mathrm{C}$. Its specific heat $C p$ is $4000 \mathrm{~J} \cdot \mathrm{kg}^{-1} \cdot \mathrm{K}^{-1}$.

For the ice slurry process, the freezing temperature of sea water is $-2{ }^{\circ} \mathrm{C}$. The mass of frozen water is assumed to correspond to $30 \%$ of the total mass of water $m$ cooled by the ice slurry process producing (equation 7 ). The latent heat of fusion $L_{f u}$ is $333.6 \mathrm{~kJ} \cdot \mathrm{kg}^{-1}$.

$\mathrm{m} \cdot \mathrm{Cp} \cdot \Delta \mathrm{T}+30 \% \cdot \mathrm{m} \cdot \mathrm{L}_{\mathrm{fu}}=\mathrm{Q}_{\mathrm{c}}$ 
The cooling and electric ratios are calculated by equations 8 and 9 respectively. $V$ corresponds to the volume of desalinated water produced.

$$
\begin{aligned}
& \text { cooling ratio }=\frac{Q_{c}}{V} \\
& \text { electric ratio }=\frac{W+\text { electric consumption for } R O}{V}
\end{aligned}
$$

\subsection{Results and discussion}

\subsubsection{Comparison of systems at the average ambient temperature of Dakar Senegal}

Table 4 presents the comparison of coupled systems with the average ambient temperature of Dakar Senegal. The weather data files are the ones used in Trnsys software [37] simulating a typical meteorological year. The first column corresponds to a HPS producing cooling energy for a chilled water loop at $5{ }^{\circ} \mathrm{C}$ for air-conditioning and desalinated water by an air gap membrane distillation unit. Considering temperature pinches in water evaporator and condenser of $5 \mathrm{~K}$, the evaporating temperature is thus $0{ }^{\circ} \mathrm{C}$ and the condensing temperature is $45^{\circ} \mathrm{C}$ for sea water heating at $40{ }^{\circ} \mathrm{C}$. For $1 \mathrm{~m}^{3}$ of desalinated water, the cooling energy production is $1100 \mathrm{kWh}$ and the electric ratio is $358.2 \mathrm{kWh}$ as in [82]. The comparison is made for an equivalent cooling energy production for all coupled systems. The ice slurry process operates with an evaporating temperature of $-7{ }^{\circ} \mathrm{C} ; 5$ $\mathrm{K}$ below the freezing temperature. The condensing temperature is $12 \mathrm{~K}$ above the average ambient temperature of Dakar.

With the same amount of cooling energy, the mass of ice assumed equal to the desalinated water production of the ice slurry process (system (2)) is more than 6 times higher than the desalinated water volume obtained by the HPS + MD process (system (1)). The cooling ratio and the electric ratio are calculated by dividing respectively the cooling energy and the electric energy by the water production volume. The ice slurry process shows a much better performance for desalinated water production. However, in this system, the heat rejected at the condenser is lost. When the membrane distillation unit is coupled to the ice slurry process (system (3)), the condensing temperature is increased at $45^{\circ} \mathrm{C}$. The thermodynamic cycle performance in terms of EER drops to 2.5 , the heating energy for desalination is higher and the water production from the distillation unit slightly increases. However, the electric consumption per cubic meter of desalinated water increases compared to the 
ice slurry process alone.

The last column of table 4 reports the values for the association of a chiller and a reverse osmosis unit (system (4)) that would produce the same amount of cooling energy and desalinated water as the coupled ice slurry and membrane distillation unit. The electric energy consumption of the reverse osmosis system is $3 \mathrm{kWh}$ per cubic metre of desalinated water. With the mean ambient temperature of Dakar, the cooling system EER is very high and the electric energy ratio is much lower. The fact of coupling the systems seems a priori not interesting in these conditions in terms of performance. However, the performance of systems has to be assessed in other conditions. The ambient temperature and the hot sea water in the MD unit will be varied.

Table 4: Comparison of coupled systems

\begin{tabular}{|c|c|c|c|c|}
\hline & (1) HPS + MD & (2) Ice Slurry & $\begin{array}{l}\text { (3) Coupled Ice } \\
\text { slurry + MD }\end{array}$ & (4) Chiller + RO \\
\hline $\mathrm{T}_{\mathrm{amb}}\left({ }^{\circ} \mathrm{C}\right)$ & N/A & 24.5 & N/A & 24.5 \\
\hline $\mathrm{T}_{\mathrm{ev}}\left({ }^{\circ} \mathrm{C}\right)$ & 0 & -7 & -7 & 0 \\
\hline $\mathrm{T}_{\text {cd }}\left({ }^{\circ} \mathrm{C}\right)$ & 45 & 36.5 & 45 & 36.5 \\
\hline $\operatorname{EER}(-)$ & 3.071 & 3.184 & 2.509 & 4.003 \\
\hline Water production $\mathrm{V}\left(\mathrm{m}^{3}\right)$ & 1 & 6.32 & 7.37 & 7.37 \\
\hline $\mathrm{Q}_{c}(\mathrm{kWh})$ & 1100 & 1100 & 1100 & 1100 \\
\hline$Q_{h}(k W h)$ & 1458 & 1446 & 1538 & 1485 \\
\hline W (kWh) & 358 & 345 & 438 & 297 \\
\hline Comment & $\begin{array}{l}\text { low water } \\
\text { production }\end{array}$ & $\begin{array}{l}\text { heat lost at } \\
\text { condenser }\end{array}$ & $\begin{array}{l}\text { Lowest feed } \\
\text { water tested } \\
\text { temperature for } \\
\text { MD [89] }\end{array}$ & $\begin{array}{l}\text { heat lost at } \\
\text { condenser }\end{array}$ \\
\hline Cooling ratio $\left(\mathrm{kWh}_{\mathrm{th}} / \mathrm{m}^{3}\right)$ & 1100 & 174 & 149 & 149 \\
\hline Electric ratio $\left(\mathrm{kWh}_{\mathrm{e}} / \mathrm{m}^{3}\right)$ & 358 & 54.7 & 59.5 & 40.3 \\
\hline
\end{tabular}

\subsubsection{Evolution of the performance of systems depending on ambient temperature}

A comparison of systems (2), (3) and (4) with varied ambient temperatures at condensers is presented in figure 9. The coupled ice slurry + MD unit system is independent on ambient temperature. The condensing temperature is set $5 \mathrm{~K}$ above the hot sea water temperature of the MD unit whereas for systems (2) and (4), using a conventional chiller with heat rejection on ambient air, the condensing temperature is $12 \mathrm{~K}$ above the ambient temperature. At the ambient temperature of $27.3{ }^{\circ} \mathrm{C}$, the electric ratio of system (3) becomes interesting. It means that the system produces more desalinated water for the satisfaction of the same cooling demand. The 
reference chiller + RO system is more efficient than system (3) under the ambient temperature of $40{ }^{\circ} \mathrm{C}$ and always more efficient than system (2).

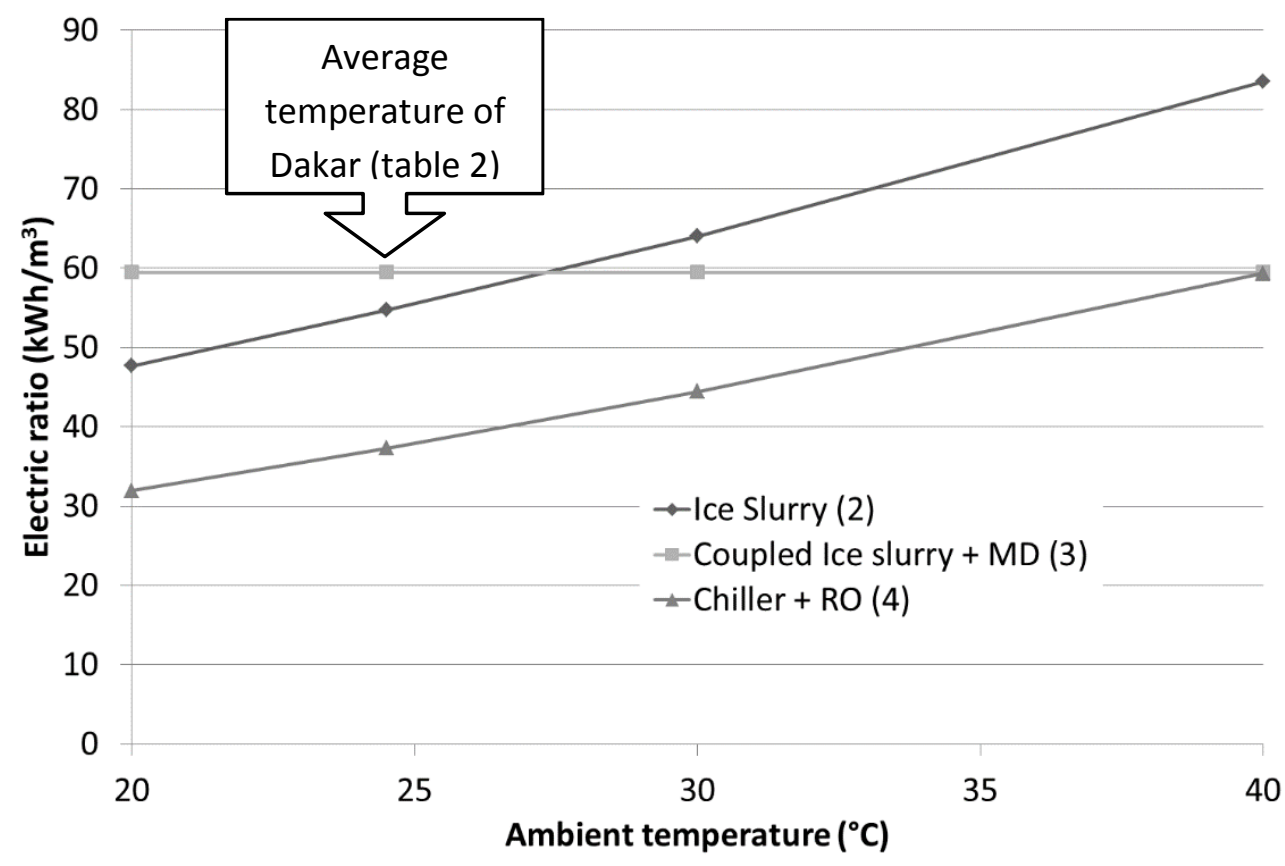

Figure 9: Comparison of performance of ice slurry, coupled ice slurry + MD and chiller + RO systems depending on ambient temperature

\subsubsection{Evolution of the performance of systems depending on the hot sea water temperature of the MD unit}

Figure 10 proposes a comparison between the coupled ice slurry + MD and the chiller + RO systems for a varied hot sea water inlet temperature in the MD unit between $25{ }^{\circ} \mathrm{C}$ and $40{ }^{\circ} \mathrm{C}$. The hot sea water temperature corresponds to $T_{i 2}$ in figure 7. The HPS + MD electric ratio, which is much higher than the other ones and the ice slurry (system (2)) electric ratio, which is constant, are not represented. Moreover, the desalinated water production of system 2 is not equal to the ones of systems (3) and (4). Thus the comparison with this system would not be correct. This temperature variation was simulated in a previous work [83] and resulted in a higher electric ratio per desalinated water volume by the MD unit. Indeed, the vapour flux through the membrane is dependent on the temperature gradient, which is reduced if the hot sea water inlet temperature decreases. For each hot sea water inlet temperature, the electric ratio of system (1) is given by the simulations of the previous publication [83] and the EER is given by Coolpack simulation results. These values enable to calculate the 
cooling energy production for this system. The other systems will produce the same amount of cooling energy. When the hot sea water inlet temperature decreases, the electric ratio and the cooling energy production increases. System (3) produces more slurry and more desalinated water. The desalinated water production of system (4) is set equal to the one of system (3). The EER of system (3) is improved significantly while the electric energy consumption of the RO unit increases to produce the same amount of desalinated water. At 25 ${ }^{\circ} \mathrm{C}$, the electric ratios for systems (3) and (4) are equivalent. This result means that a coupled system of ice slurry and membrane distillation with a low temperature feed water could be an interesting path to explore by experimental means in order to compete with standard processes in a coupled cooling and desalination system.

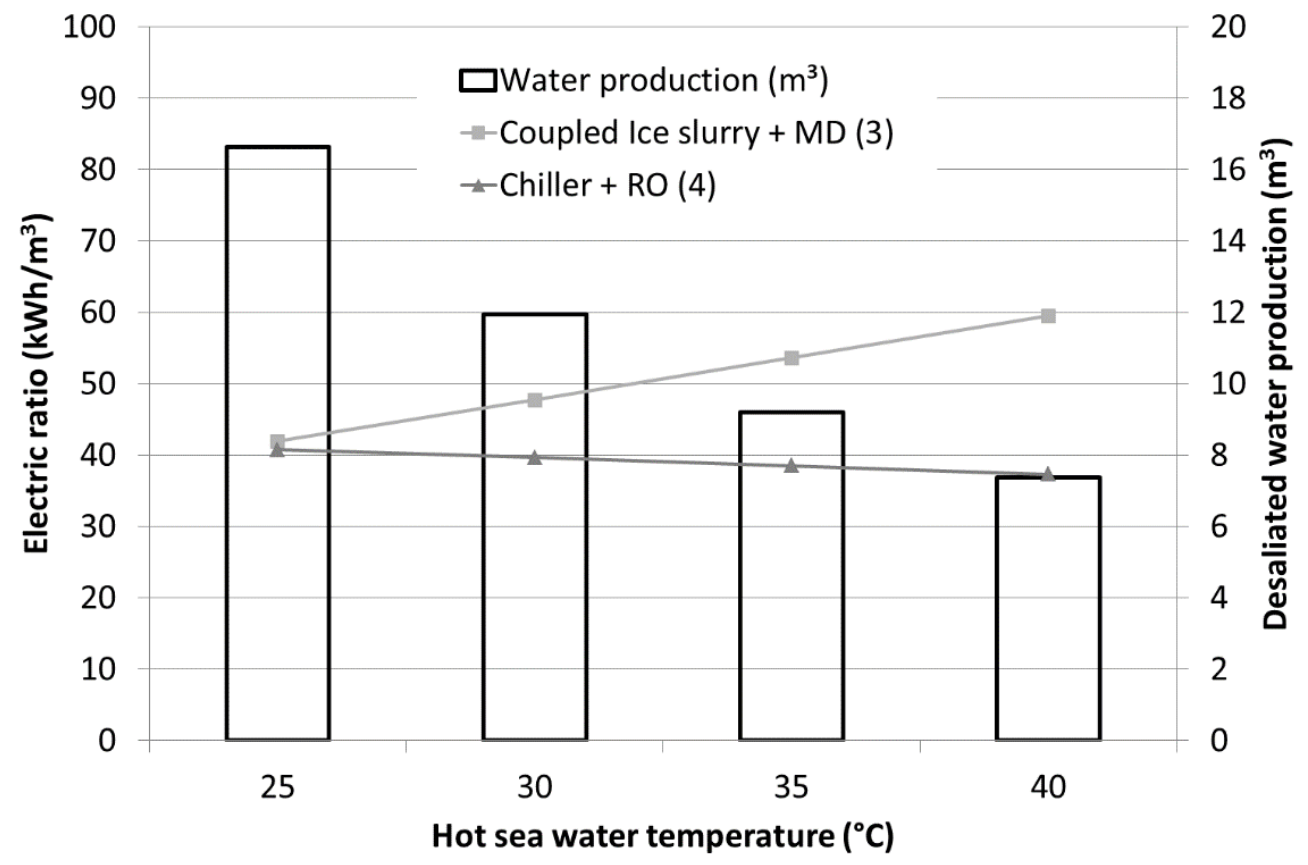

Figure 10: Comparison of performance of coupled ice slurry + MD and chiller + RO systems depending on hot sea water inlet temperature of MD unit 


\section{CONCLUSION}

The energy and water context is stressed by increasing demands and decreasing resources per person in the world. Coupling cooling, desalination and solar photovoltaic systems seems an interesting solution to carry out energy and water savings in southern coastal cities or remote inland villages. Solar energy is one of the most promising among renewable energies. Solar photovoltaic energy has become really attractive in recent years thanks to very low equipment cost. The review presents the main coupled technologies and the associated key factors for future development.

Refrigerating machines can cool buildings or food and desalinate water simultaneously. Two techniques were identified as the simplest to be implemented: a membrane distillation unit coupled to the condenser of a heat pump and an ice slurry process. An assessment of the performance of the coupled systems is proposed in the last section of this article. The coupled systems should operate under special conditions to outperform the reference results obtained by the association of a standard chiller and a reverse osmosis unit. Some perspectives have to be studied. MD units and desalination systems in general are relatively young technologies that should progress in the future. Membrane materials have to be tested one by one in whole scale plants to participate to a continuous improvement of this technology. Crystallisation units including the separation process should also be tested under real conditions. Finally, the coupling of cooling, desalination and PV systems should be optimized in terms of performance thanks to intelligent control and management. 


\title{
NOMENCLATURE
}

\author{
Abbreviations: \\ ABHP Absorption Heat Pump Desalination \\ ADHP Adsorption Heat Pump Desalination \\ AGMD Air Gap Membrane Distillation \\ CDD Cooling Degree Days \\ DCMD Direct Contact Membrane Distillation \\ ED Electrodialysis \\ EFC Eutectic Freeze Crystallisation \\ FM Freezing-Melting \\ GWp Gigawatt peak \\ GWP Global Water Partnership \\ HDH Humidification-Dehumidification \\ HPS Heat Pump for Simultaneous heating and cooling \\ IEA International Energy Agency \\ IPCC Intergovernmental Panel on Climate Change \\ IWRM Integrated Water Resource Management \\ LCOE Levelized Cost Of Electricity \\ MD Membrane Distillation \\ MED Multi-Effect Distillation \\ MSF Multi-Stage Flash \\ Mtoe Million tons of oil equivalent \\ MVC Mechanical Vapour Compression \\ OECD Organization for Economic Co-operation and Development \\ PCM Phase Change Material \\ PDPI Precipitation Decrease Per Inhabitant \\ PV Photovoltaic \\ PVD Passive Vacuum Desalination \\ RO Reverse Osmosis \\ SGMD Sweeping Gas Membrane Distillation \\ SR Solar Resource \\ ST Solar Still \\ SWIM Sustainable Water Integrated Management \\ TVC Thermal Vapour Compression \\ VMD Vacuum Membrane Distillation
}

\section{Latin letters:}

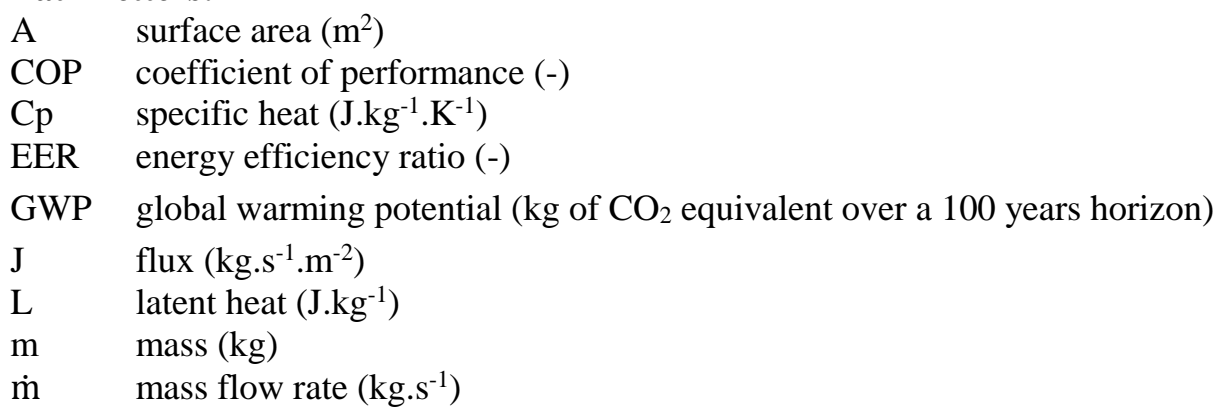


Q thermal energy (J)

$\mathrm{T}$ temperature $(\mathrm{K})$

$\mathrm{V}$ desalinated water volume $\left(\mathrm{m}^{3}\right)$

W electric energy $(\mathrm{J})$

\section{Greek letters:}

$\Delta \quad$ difference

$\varepsilon \quad$ efficiency (-)

\section{Subscripts:}

a air

amb ambient

c cooling

cd condensation

csm cold surface of membrane

ev evaporation

f film

fu fusion

h heating

hsm hot surface of membrane

$\mathrm{i}$ in

m membrane

o out

v vapour

w water

\section{Superscripts:}

ave average

rel relative 


\section{REFERENCES}

[1] International Energy Agency. Key World Energy Statistics from the IEA; 2013.

[2] Yun GY, Steemers K. Behavioural, physical and socio-economic factors in household cooling energy consumption. Appl Energ 2011;88:2191-2200.

[3] Gupta E. Global warming and electricity demand in the rapidly growing city of Delhi: A semi-parametric variable coefficient approach. Energ Econ 2012;34:1407-1421.

[4] United Nations, Department of Economic and Social Affairs, Population Division. World Urbanization Prospects: The 2011 Revision; 2012.

[5] Allegrini J, Dorer V, Carmeliet J. Influence of the urban microclimate in street canyons on the energy demand for space cooling and heating of buildings. Energ Buildings 2012;55:823-832.

[6] Ren Z, Paevere P, Grozev G, Egan S, Anticev J. Assessment of end-use electricity consumption and peak demand by Townsville's housing stock. Energ Policy 2013;61:888-893.

[7] Intergovernmental Panel on Climate Change IPCC. Climate change 2007: the physical science basis; 2007.

[8] Sadineni SB, Boehm RF. Measurements and simulations for peak electrical load reduction in cooling dominated climate. Energy 2012;37:689-697.

[9] Agence de l'Environnement et de la Maîtrise de l'Energie ADEME. Les chiffres clés 2013 climat, air et énergie; 2014.

[10] Mugnier D. Task 53 Description and Work Plan, International Energy Agency, Solar Heating and Cooling Programme; 2012.

[11] Sivak M. Potential energy demand for cooling in the 50 largest metropolitan areas of the world: Implications for developing countries. Energ Policy 2009;37:1382-1384.

[12] Elzinga D, Fulton L, Heinen S, Wasilik O. Advantage Energy, Emerging Economies, Developing Countries and the Private-Public Sector Interface. International Energy Agency; 2011.

[13] Sun Y, Wang S, Xiao F, Gao D. Peak load shifting control using different cold thermal energy storage facilities in commercial buildings: A review. Energ Convers Manage 2013;71:101-114.

[14] International Energy Agency. The Power to choose: demand response in liberalized electricity markets. Organization for economic co-operation and development (OECD) and international energy agency (IEA); 2003.

[15] Hasnain SM. Review on sustainable thermal energy storage technologies. Part II: cool thermal storage. Energ Convers Manage 1998;39:1139-1153.

[16] Hasnain SM, Alawaji SH, Al-Ibrahim AM, Smiai MS. Prospects of cool thermal storage utilization in Saudi Arabia. Energ Convers Manage 2000;41:1829-1839.

[17] Yau YH, Rismanchi B. A review on cool thermal storage technologies and operating strategies. Renew Sust Energ Rev 2012;16:787-797.

[18] Lee KH, Braun JE. Model-based demand-limiting control of building thermal mass. Build Environ 2008;43:1633-1646.

[19] Qureshi WA, Nair NKC, Farid MM. Impact of energy storage in buildings on electricity demand side management. Energ Convers Manage 2011;52:2110-2120.

[20] Ban M, Krajacic G, Grozdek M, Curko T, Duic N. The role of cool thermal energy storage (CTES) in the integration of renewable energy sources (RES) and peak load reduction. Energy 2012;48:108-117.

[21] Bruno F, Tay NHS, Belusko M. Minimising energy usage for domestic cooling with off-peak PCM storage. Energ Buildings 2014;76:347-353.

[22] Meunier F, Mugnier D. La climatisation solaire. Editions Dunod; 2013.

[23] International Energy Agency. Solar Heating and Cooling, Technology Roadmap. Organization for economic co-operation and development (OECD) and international energy agency (IEA); 2012.

[24] Tyagi VV, Rahim NAA, Rahim NA, Selvaraj JAL. Progress in solar PV technology: Research and achievement. Renew Sust Energ Rev 2013;20:443-461

[25] PVPS Report, A Snapshot of Global PV 1992-2012, Preliminary information from the IEA PVPS Programme. International Energy Agency, Photovoltaic Power Systems Programme; 2013.

[26] Liu X, O’Rear EG, Tyner W, Pekny JF. Purchasing vs. leasing: A benefit-cost analysis of residential solar PV panel use in California. Renew Energ 2014;66:770-774. 
[27] Ondraczeka J, Komendantovab N, Patt A. WACC the dog: The effect of financing costs on the levelized cost of solar PV power. Renew Energ 2015;75;888-898.

[28] World Business Council for Sustainable Development. Water facts and trends. The WBCSD Water and Sustainable Development Program; 2005.

[29] Stocker TF, Qin D, Plattner GK, Tignor M, Allen SK, Boschung J, Nauels A, Xia Y, Bex V, Midgley

PM. IPCC, 2013: Summary for Policymakers. In: Climate Change 2013: The Physical Science Basis.

Contribution of Working Group I to the Fifth Assessment Report of the Intergovernmental Panel on Climate

Change. Cambridge University Press, Cambridge, United Kingdom and New York, NY, USA; 2013.

[30] United Nations World Water Assessment Programme WWAP. The United Nations World Water

Development Report 2014: Water and Energy. Paris, UNESCO; 2014.

[31] Li C, Goswami Y, Stefanakos E. Solar assisted sea water desalination: A review. Renew Sust Energ Rev 2013;19:136-163.

[32] Williams PM, Ahmad M, Connolly BS, Oatley-Radcliffe DL. Technology for freeze concentration in the desalination industry. Desalination; 2014. http://dx.doi.org/10.1016/j.desal.2014.10.023

[33] Ghaffour N, Bundschuh J, Mahmoudi H, Goosen MFA. Renewable energy-driven desalination technologies: a comprehensive review on challenges and potential applications of integrated systems.

Desalination; 2015;356;94-114.

[34] Luca L, Glavanny J, Rapport d'information à l'Assemblée Nationale sur « La géopolitique de l'eau »; 2011.

[35] Lauvergeon A et al. Un principe et sept ambitions pour la France, Rapport de la Commission Innovation 2030 au gouvernement; 2013.

[36] http://www.citypopulation.de

[37] Klein SA et al. TRNSYS 17: A Transient System Simulation Program, Solar Energy Laboratory,

University of Wisconsin, Madison, USA; 2010. http://sel.me.wisc.edu/trnsys

[38] Elimelech M, Phillip WA. The future of seawater desalination: energy, technology and the environment. Science 2011;333:712-717.

[39] Mezher T, Fath H, Abbas Z, Khaled A. Techno-economic assessment and environmental impacts of desalination technologies. Desalination 2011;266:263-273.

[40] Tanaka H, Ho YS. Global trends and performances of desalination research. Desalin Water Treat 2011;25:1-12.

[41] Zak MG, Mitsos A. Hybrid thermal desalination structures, Desalin Water Treat 2014;52:2905-2919.

[42] http://www.water-technology.net/projects/-ras-al-khair-desalination-plant

[43] Misra BM, Kupitz J. The role of nuclear desalination in meeting the potable water needs in water scarce areas in the next decades. Desalination 2004;166:1-9.

[44] Tian L, Guo J, Tang Y, Cao L. A historical opportunity: economic competitiveness of seawater desalination project between nuclear and fossil fuel while the world oil price over $\$ 50$ per boe - part A: MSF. Desalination 2005; 183:317-325.

[45] Jung HH, Lee WH, Kim JH. Feasibility study on tri-hybrid desalination system, Desalin Water Treat 2010;15:35-42.

[46] Wang P, Chung TS. Recent advances in membrane distillation processes: Membrane development, configuration design and application exploring. J Membrane Sci 2015;474:39-56.

[47] Jonsson AS, Wimmerstedt R, Harrysson AC. Membrane distillation - A theoretical study of evaporation through microporous membranes. Desalination 1985;56:237-249.

[48] Mericq JP. Approche intégrée du dessalement d'eau de mer : Distillation membranaire sous vide pour la réduction des rejets salins et possibilités de couplage avec l'énergie solaire, Thèse de doctorat, INSA de Toulouse, France; 2009.

[49] Lawson KW, Lloyd DR. Membrane distillation. J Membrane Sci 1997;124:1-25.

[50] Alklaibi AM, Lior N. Membrane-distillation desalination: status and potential. Desalination 2004;171:111-131.

[51] Alklaibi AM, Lior N. Transport analysis of air-gap membrane distillation. J Membrane Sci 2005;255:239-253.

[52] Fang H, Gao JF, Wang HT, Chen CS. Hydrophobic porous alumina hollow fiber for water desalination via membrane distillation process. J Membrane Sci 2012;403-404;41-46. 
[53] Charcosset C. A review of membrane processes and renewable energies for desalination. Desalination 2009;245:214-231.

[54] Drioli E, Ali A, Macedonio F. Membrane distillation: Recent developments and perspectives.

Desalination 2014; http://dx.doi.org/10.1016/j.desal.2014.10.02

[55] Alkhudhiri, A., Darwish, N. \& Hilal, N. Membrane distillation: A comprehensive review. Desalination 287, 2-18 (2012).

[56] http://www.aquaver.com/inaugurated-in-the-maldives-the-first-desalination-plant-powered-by-waste-heat [57] Fujioka R, Wang LP, Dodbiba G, Fujita T. Application of progressive freeze-concentration for desalination, Desalination2013;319:33-37.

[58] Attia AAA. New proposed system for freeze water desalination using auto reversed R-22 vapor compression heat pump. Desalination 2010;254:179-184.

[59] Rane MV, Padiya YS. Heat pump operated freeze concentration system with tubular heat exchanger for seawater desalination. Energ Sust Dev 2011;15:184-191.

[60] Stepakoff GL, Siegelman D, Johnson R, Gibson W. Development of a eutectic freezing process for brine disposal. Desalination 1974;14:25-38.

[61] Van der Ham F, Witkamp GJ, De Graauw J, Van Rosmalen GM. Eutectic freeze crystallization: application to process streams and waste water purification. Chem Eng Process 1998;37:207-213.

[62] Van der Ham F, Witkamp GJ, De Graauw J, Van Rosmalen GM. Eutectic freeze crystallization simultaneous formation and separation of two solid phases. J Cryst Growth 1999;198-199:744-748.

[63] Himawan C, Vaessen RJC, Kramer HJM, Seckler MM, Witkamp GJ. Dynamic modeling and simulation of eutectic feeze crystallization. J Cryst Growth 2002;237-239:2257-2263.

[64] Vaessen RJC, Seckler MM, Witkamp GJ. Heat transfer in scraped eutectic crystallizer. Int J Heat Mass Tran 2004;47:717-728.

[65] Fernández-Torres MJ, Randall DG, Melamu R, Von Blottnitz H. A comparative life cycle assessment of eutectic freeze crystallisation and evaporative crystallisation for the treatment of saline wastewater.

Desalination 2012;306:17-23.

[66] Randall DG, Nathoo J, Lewis AE. A case study for treating a reverse osmosis brine using eutectic freeze crystallisation - approaching a zerowaste process. Desalination 2011;266:256-262.

[67] Nathoo J, Jivanji R, Lewis AE. Freezing your brines off: eutectic freeze crystallization for brine treatment, in: InternationalMineWater Conference, Pretoria, South Africa 2009;431-437.

[68] Mittelman G, Mouchtarm O, Dayan A. Large scale solar thermal desalination plants: A review, Heat Tran Eng 2007;28:924-930.

[69] Colombo D, De Gerloni M, Reali M. An energy-efficient submarine desalination plant. Desalination 1999;122:171-176.

[70] Garcia-Rodriguez L. Renewable energy applications in desalination: state of the art. Sol Energy 2003;75:381-393.

[71] Greenlee LF, Lawler DF, Freeman BD, Marrot B, Moulin P. Reverse osmosis desalination: Water sources, technology, and today's challenges. Water Res 2009;43:2317-2348.

[72] Lee KP, Arnot TC, Mattia D. A review of reverse osmosis membrane materials for desalination-

Development to date and future potential. J Membrane Sci 2011;370:1-22.

[73] Mathioulakis E, Belessiotis V, Delyannis E. Desalination by using alternative energy: Review and stateof-the-art. Desalination 2007;203:346-365.

[74] Grubert EA, Stillwell AS, Webber ME. Where does solar-aided seawater desalination make sense? A method for identifying sustainable sites. Desalination 2014;339:10-17.

[75] Ferreira CI, Kim DS. Techno-economic review of solar cooling technologies based on location-specific data. Int J Refrig 2014;39:23-37.

[76] Lazzarin R. Solar cooling: PV or thermal? A thermodynamic and economical analysis. Int J Refrig 2014;39:38-47.

[77] Otanicar T, Taylor RA, Phelan PE. Prospects for solar cooling - An economic and environmental assessment. Sol Energy 2012;86:1287-1299.

[78] Aguilar FJ, Quiles PV, Aledo S. Operation and energy efficiency of a hybrid air conditioner simultaneously connected to the grid and to photovoltaic panels. Energ Procedia 2014;48;768-777.

[79] Herrera E, Bourdais R, Gueguen H. Predictive and interactive controllers for solar absorption cooling systems in buildings, J Process Contr 2014;24:836-845. 
[80] Slesarenko VV. Heat pumps as a source of heat energy for desalination of seawater. Desalination 2001;139:405-410.

[81] Byrne P, Miriel J, Serres L, Ghoubali R. Etude simulée d'un système de dessalement d'eau de mer et de production de froid par thermofrigopompe couplée à des panneaux solaires. 2ème Colloque International Francophone en Energétique et Mécanique, CIFEM 2012, 2 - 4 mai 2012, Ouagadougou, Burkina Faso; 2012. [82] Byrne P, Ait Oumeziane Y, Serres L, Miriel J. Etude simulée d'un système de distillation membranaire pour le dessalement d'eau de mer couplé à une thermofrigopompe, 3ème Colloque International Francophone en Energétique et Mécanique, CIFEM 2014, 3 - 5 mai 2014, Moroni, Comores; 2014.

[83] Byrne P, Ait Oumeziane Y, Serres L, Miriel J. Study of a heat pump for simultaneous cooling and desalination, IMAT Conference, 26 - 27 November 2014, Kuala Lumpur, Malaysia; 2014.

[84] Ghaffour N, Lattemann S, Missimer T, Ng KC, Sinha S, Amy G. Renewable energy-driven innovative energy-efficient desalination technologies. Int J Refrig 2014;39:23-37.

[85] http://www.ibm.com/ibm/responsibility/corporateservicecorps/solar.html

[86] Schies A. Technological and economic assessment PV-diesel hybrid solutions versus other technologies.

PEP Information Workshop: PV-Hybrid Systems in Indonesia. Berlin; 2013.

[87] Ghoubali R, Byrne P, Miriel J, Bazantay F. Simulation study of heat pumps for simultaneous heating and cooling coupled to buildings. Energ Buildings 2014;72:141-149.

[88] Byrne P, Miriel J, Lénat Y. Design and simulation of a heat pump for simultaneous heating and cooling using HFC or CO2 as a working fluid. Int J Refrig 2009;32:1711-1723.

[89] Banat FA. Membrane distillation for desalination and removal of volatile organic compounds from water. Doctoral Thesis, McGill University, Montreal, Canada; 1994.

[90] Guilpart J, Stamatiou E, Delahaye A, Fournaison L. Comparison of the performance of different ice slurry types depending on the application temperature. Int J Refrig 2006;29:781-788.

[91] Johnson WE. State of the art of freezing processes, their potential and future. Desalination 1976;19:349358.

[92] Maguire JB. Fresh water from the sea, A new process. Desalination 1987;67:155-162.

[93] Johnson WE. Indirect freezing, Desalination 1979;31:417-425.

[94] Curran HM. Water desalination by indirect freezing. Desalination 1970;7:273-284.

[95] Abdul-fattah AF. Use of low grade in driving small freezing units for desalination. Desalination 1987;61:169-183.

[96] Madani AA, Aly SE. A combined RO/freezing system to reduce inland rejected brine. Desalination 1989;75:241-258.

[97] Papapetrou M, Wieghaus M, Biercamp C. Roadmap for the development of desalination powered by renewable energy. PRODES project: Promotion of renewable energy for water production through desalination, Fraunhofer Verlag; 2010.

[98] Bushnak A. Evaluation des meilleures technologies disponibles pour le dessalement en zones rurales/locales. Gestion Intégrée Durable de l'Eau - Mécanisme de Soutien (SWIM-SM), 2013. [99] Technical University of Denmark, Department of Mechanical Engineering. Coolpack, A Collection of Simulation Tools for Refrigeration; 1997-2001.

[100] Klein SA, Alvarado FL. EES - Engineering Equation Solver, F-Chart software, Wisconsin, USA; 2000. 


\section{HIGHLIGHTS}

Solar resource, cooling demands and desalination needs are correlated

Coupling systems is an interesting way to make energy savings

Membrane distillation and ice slurry are compatible with refrigeration machines

Some development has to be made to manage the coupled systems 